Review

\title{
Conversion of Carbon Dioxide: Opportunities and Fundamental Challenges
}

\author{
${ }^{1}$ Sajeda A. Al-Saydeh, ${ }^{1}$ Syed J. Zaidi and ${ }^{2}$ Muftah H. El-Naas \\ ${ }^{I}$ Center for Advanced Materials (CAM), Qatar University, Doha, Qatar \\ ${ }^{2}$ Gas Processing Center (GPC), Qatar University, Doha, Qatar
}

\author{
Article history \\ Received: 11-12-2017 \\ Revised: $14-12-2017$ \\ Accepted: 4-01-2018 \\ Corresponding Author: \\ Syed J. Zaidi \\ Center for Advanced Materials \\ (CAM), Qatar University, \\ Doha, Qatar \\ Tel: +97444037723 \\ Email: szaidi@qu.edu.qa
}

\begin{abstract}
The rising atmospheric levels of carbon dioxide is one of the most urgent challenges facing societies nowadays. There is also great potential in energy carriers and other materials from $\mathrm{CO}_{2}$, with many challenges to overcome. The way to reduce greenhouse gas emissions should be using carbon free sources that do not generate carbon dioxide to the atmosphere. This article reviews recent developments, remaining challenges and novel approaches of $\mathrm{CO}_{2}$ reduction for the efficient and sustainable production of fuels and valuable chemicals. It has been suggested that the $\mathrm{CO}_{2}$ reduction and conversion may provide promising solutions for energy resource scarcity as well as reduction of greenhouse gas emissions. Hence, this paper discusses novel technologies and approaches to reduce carbon dioxide to produce energy and chemicals through heterogeneous catalysis, electrocatalysis and photocatalysis, which will contribute to the economic growth and mitigate the hazardous emissions for cleaner environment. A review of the state-of-the-art of various technologies for carbon dioxide reduction was carried out aiming to demonstrate the advances in this area and provide an overview of the research trend for future development of new ideas for $\mathrm{CO}_{2}$ reduction in a large scale.
\end{abstract}

Keywords: $\mathrm{CO}_{2}$ Utilization, Heterogeneous Catalysis, Electrocatalysis, Photocatalysis, Photoelectrocatalysis

\section{Introduction}

Carbon dioxide, which is considered as a primary Greenhouse-Gas (GHG), is periodically exchanged within land surface, ocean and atmosphere where a variety of creatures, including animals, plants and microorganisms absorb and produce it daily. However, the process of releasing and consuming $\mathrm{CO}_{2}$ trends has to be balanced by nature. Since 1750, when the industrial revolution began, so did climate change, following the activities related to industries (USEPA, 2016). Nowadays, the demand of energy is rapidly increasing because of the economic growth worldwide. In order to meet this growing demand, an abundant amount of fossil fuel (oil, coal and natural gas) is needed (Leung et al., 2014). Fossil fuel combustion is often considered as one of the main threats to the environment because of the $\mathrm{CO}_{2}$ release in the atmosphere. Studies have shown that around $78 \%$ of the total $\mathrm{CO}_{2}$ emission was released by fossil fuel combustion and other industrial processes within the period from 2000 to 2010. Further, in 2014, $\mathrm{CO}_{2}$ emission was about $80.9 \%$ of all U.S greenhouse gases emissions and it reached around 5500 million metric tons (Fig. 1) greenhouse gas emission (Luu et al., 2015). In the United States, the main purposes for the combustion of fossil fuel are electricity production, transportation and some industrial processes, which are the sources of $\mathrm{CO}_{2}$ emissions as shown in Fig. 2. These sources are described below (USEPA, 2016).

\section{Electricity Production}

The first largest source of $\mathrm{CO}_{2}$ emission in the U.S. is fuel burning to generate electricity. The amounts of $\mathrm{CO}_{2}$ emitted from producing electricity are based on the type of fossil fuel used; for example, burning coal will emit more $\mathrm{CO}_{2}$ compared to the burning of oil or natural gas. In which the burning of coal and natural gas can produce around 228.6 and 117.0 Btu respectively as mentioned by U.S. Energy Information Administration (USEIA, 2016). 


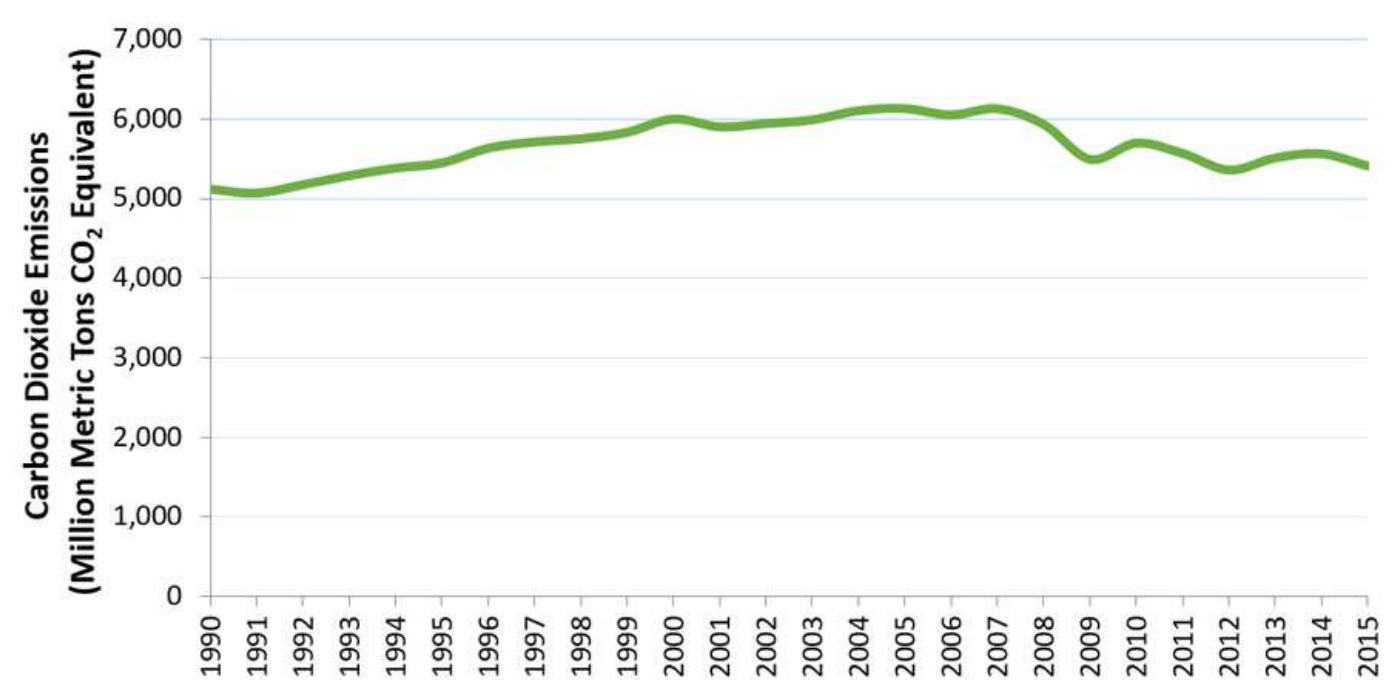

Fig. 1: The emission of $\mathrm{CO}_{2}$ in the U.S. (1990-2014) (USEPA, 2016)

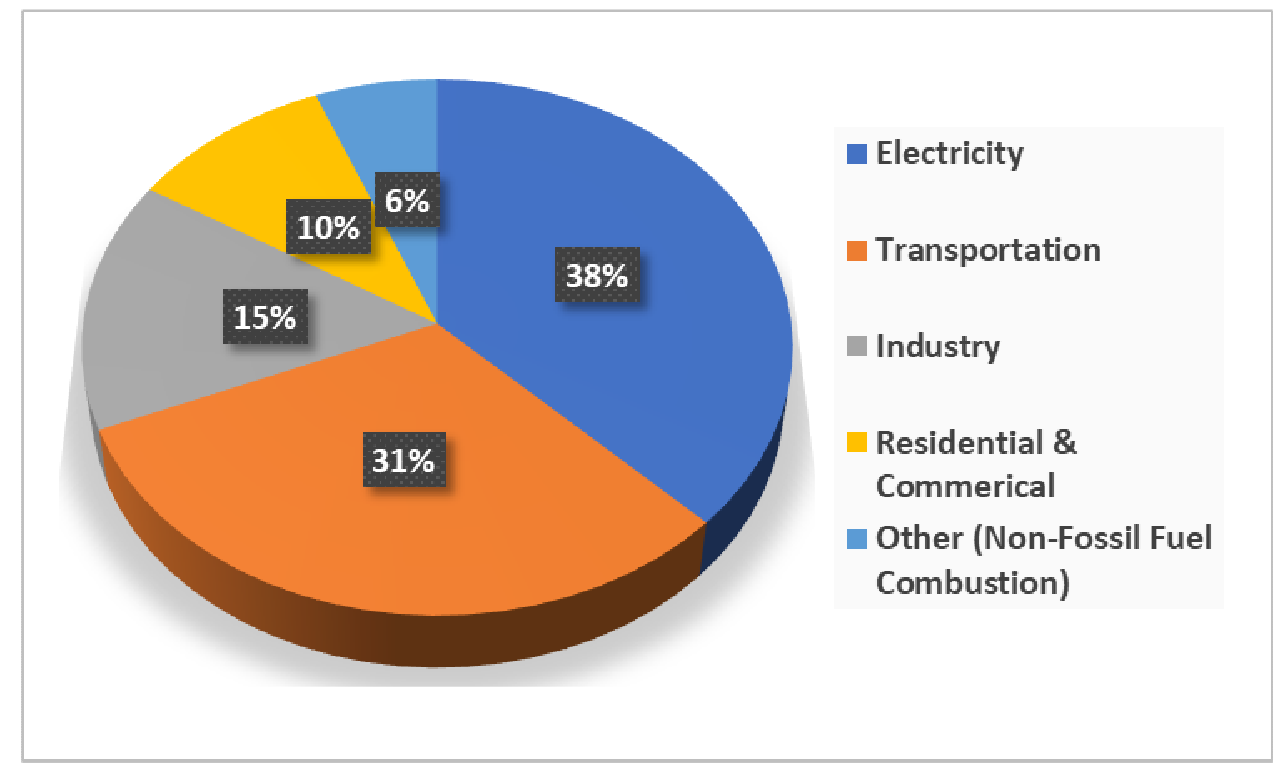

Fig. 2: Sources of $\mathrm{CO}_{2}$ emission in the U.S. (1990-2014) (USEPA, 2016)

\section{Transportation}

Transportation sources such as air travel, highway vehicles, rail and marine transportation, combust considerable amounts of fossil fuels like diesel and gasoline. The transportation sector occupies the second largest source of $\mathrm{CO}_{2}$ emissions in the U.S.

\section{Industrial Processes}

$\mathrm{CO}_{2}$ can be emitted from industrial plants in two ways: Burning the fossil fuel through the industrial processes and producing $\mathrm{CO} 2$ through the chemical reactions without involving the combustion such as producing cement, which is one of the mineral products and producing the metals such as steel and iron. Furthermore, industries can be the indirect cause of $\mathrm{CO}_{2}$ emission by generating and using electricity. The harmful effects of the presence of greenhouse gases in atmosphere are global warming, ozone depletion, climate change and sea level rise. Wherefore, the higher concentrations of greenhouse gases in the atmosphere mean more solar radiation was trapped within the atmosphere, making the temperatures rise (Guemene Dountio et al., 2016).

However, considering this situation it will be difficult in the coming few decades to reduce the $\mathrm{CO}_{2}$ emissions in order to reach the allowed limits and the reason is that the burning of fossil fuel will continue being the main source of energy (Huang and Tan, 2014). In order to solve this problem, two $\mathrm{CO}_{2}$ emission reduction strategies can be used, namely $\mathrm{CO}_{2}$ Capture and Storage 
(CCS) and $\mathrm{CO}_{2}$ utilization (Hurst et al., 2012; Qu and Duan, 2012). However, the utilization of $\mathrm{CO}_{2}$ is more preferable since it results in converting this harmful gas into valuable products. Low cost, pure $\mathrm{CO}_{2}$ can be easily obtained from CCS plants (Benson et al., 2009; Centi and Perathoner, 2009; Hossain, 2012). Moreover, many factors support the utilization of $\mathrm{CO}_{2}$ in the production of different useful products, some of them listed below (Arakawa et al. 2001):

- It is considered as in expensive, nontoxic compound which can replace some toxic compounds such as isocyanates

- The conversion of $\mathrm{CO}_{2}$ can produce totally new materials (i.e., Polymers)

- New way which is more efficient and economical to produce chemical products compared to conventional methods
As a result, the chemical conversion of $\mathrm{CO}_{2}$ to renewable fuel and useful chemicals is considered as the most attractive way to mitigate the $\mathrm{CO}_{2}$ emissions due to the high potential market and promising benefits (Centi and Perathoner, 2009). Table 1 presents the products that can be formed through $\mathrm{CO}_{2}$ conversion process with their potential of $\mathrm{CO}_{2}$ reduction and market scale. This paper gives an overview of $\mathrm{CO}_{2}$ utilization in which the challenges and opportunities of $\mathrm{CO}_{2}$ utilization are discussed, because $\mathrm{CO}_{2}$ utilization and conversion is considered as an integral part of carbon management. Reviewing these different catalytic methods will be the focus of the review paper. During the last few years, numerous studies have been proved towards the utilization of $\mathrm{CO}_{2}$ through different methods such as heterogeneous catalysis, electrocatalysis and photocatalysis (Jovanov et al., 2016; Kumar et al., 2016; Roy et al., 2010).

Table 1: Potential of $\mathrm{CO}_{2}$ reduction and market scale for products that can be formed by $\mathrm{CO}_{2}$ conversion process

\begin{tabular}{|c|c|c|c|c|}
\hline \multirow[b]{2}{*}{ Product } & \multirow{2}{*}{$\begin{array}{l}\text { Potential of } \mathrm{CO}_{2} \text { reduction } \\
\text { (ton } \mathrm{CO}_{2} / \text { ton of product) }\end{array}$} & \multicolumn{2}{|c|}{ Market scale (per year) } & \multirow[b]{2}{*}{ References } \\
\hline & & Global demand & Market value & \\
\hline Dimethyl ether (DME) & 1.9 & $6.3 \mathrm{MT}$ & $\$ 3.2$ billion & (Huang and Tan, 2014) \\
\hline Dimethyl carbonate (DMC) & 1.47 & $0.24 \mathrm{MT}$ & $\$ 280$ billion & (Huang and Tan, 2014) \\
\hline Methanol & 1.38 & $75 \mathrm{MT}$ & $\$ 36$ billion & $(2013)$ \\
\hline Polycarbonate & 0.5 & $3.6 \mathrm{MT}$ & $\$ 14.4$ billion & (Huang and Tan, 2014) \\
\hline Urea & $0.735-0.75$ & 198.4 MT & $\$ 59.5$ billion & (Heffer $\mathrm{PaPh}, 2013$ ) \\
\hline
\end{tabular}

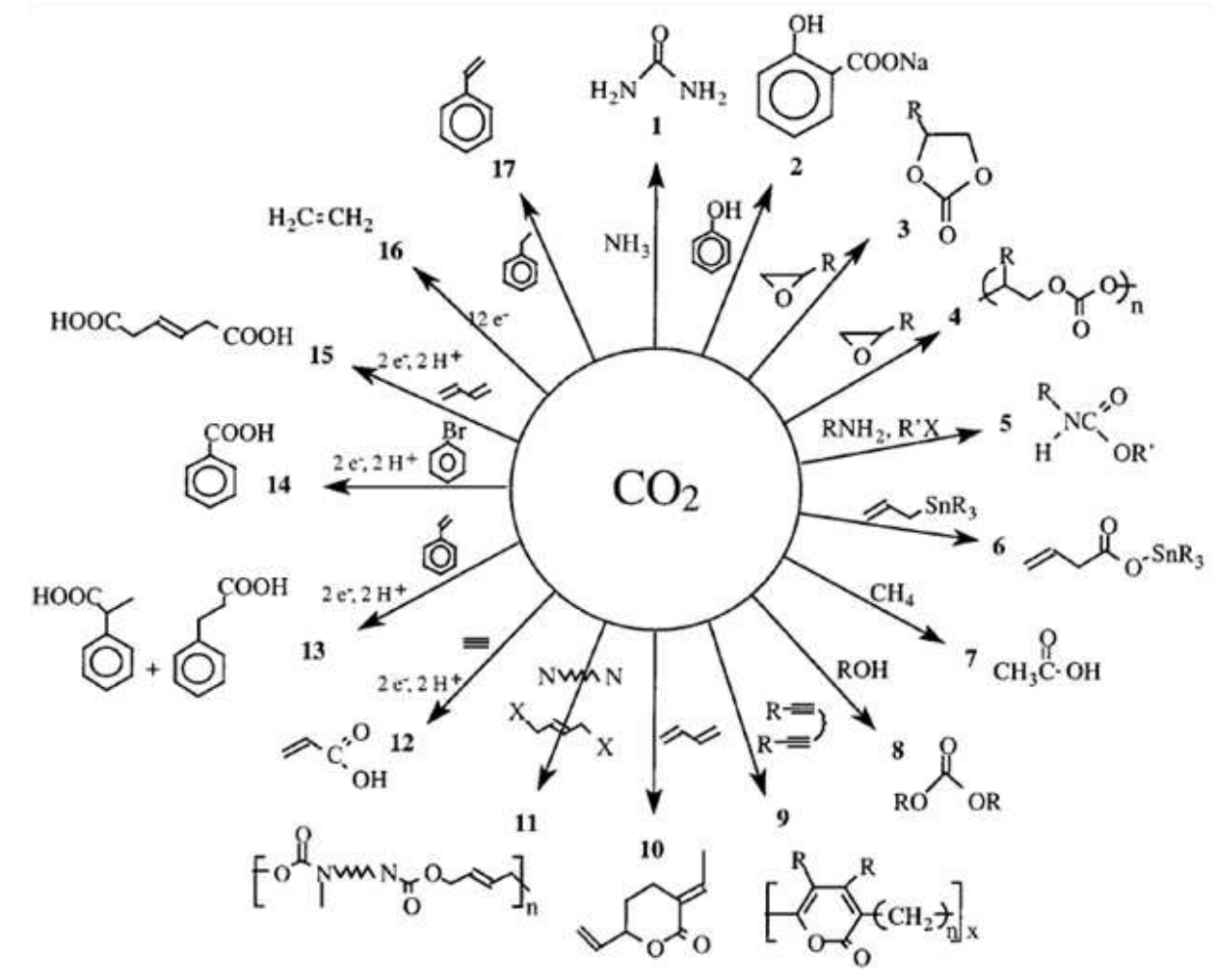

Fig. 3: $\mathrm{CO}_{2}$ utilization for different chemicals (Arakawa et al., 2001) 


\section{$\mathrm{CO}_{2}$ Utilization Methods}

\section{Heterogeneous Catalysis}

Various research studies have been conducted on the $\mathrm{CO}_{2}$ conversion to useful chemicals by using heterogeneous and homogeneous catalysts. Unfortunately, under mild conditions, the heterogeneous catalysts typically show lower catalytic selectivity and activity compared to the homogeneous catalysts. However, the use of heterogeneous catalysis method has many advantages (Fujita et al., 2014). This includes high efficiency in the separation and recycling stages and the significant durability and stability in handling and reactor design. Thus, this method is widely used in the industries and is preferred to be used in the $\mathrm{CO}_{2}$ conversion process (Razali et al., 2012). Some researchers discussed the produced chemicals that are shown in (Fig. 3) which include urea (Number 1), salicylicacid (Number 2) and cyclic carbonates (Number 3 ). Urea is considered to be the largest product used, which it reached around 90 million metric tons per year in 1997. In addition to these industrial processes using $\mathrm{CO}_{2}$ (compounds 1-3 in Fig. 3 ), many processes are still under laboratory scale studies which are the remaining reactions in (Fig. 3) (Aresta and Tommasi, 1997).

Heterogeneous catalysts can convert $\mathrm{CO}_{2}$ into chemicals or intermediates such as cyclic carbonates, methanol and dimethyl carbonate. Heterogeneous catalysts include electrocatalysts, photocatalysts and photo-electro-catalysts. $\mathrm{CO}_{2}$ is currently used to convert $\mathrm{CO}$ with $\mathrm{H}_{2}$ to methanol (Aresta and Dibenedetto, 2003). During the past few years, more efficient heterogeneous catalysts have been developed for $\mathrm{CO}_{2}$ hydrogenation to methanol and pilot scale plants based on these catalysts have been tested (Inui et al., 1998). However, the thermodynamics for the reaction of methanol synthesis from $\mathrm{CO}$ is more favorable compared to that of methanol synthesis from $\mathrm{CO}_{2}$ (Kusama et al., 1996). $\mathrm{Cu} / \mathrm{ZrO}_{2} / \mathrm{SiO}_{2}$ catalysts have been studied by in-situ infrared spectroscopy and suggested the pathway to produce methanol (Fig. 4) (Fisher and Bell, 1998). Further, the production of ethanol by the hydrogenation of $\mathrm{CO}_{2}$ has been studied in 1996 by Kusama et al. (1996).

\section{Electrocatalytic $\mathrm{CO}_{2}$ Reduction}

The electrochemical reduction method is used to convert the $\mathrm{CO}_{2}$ gas to valuable chemicals and fuels such as hydrocarbons, carbon monoxide, methanol and formic acid, using electricity as the main source of energy (Fig. 5A) (Jovanov et al., 2016; Kuhl et al., 2014). The costeffective electrochemical reduction process of $\mathrm{CO}_{2}$ requires a very good electrocatalysts that are stable, selective and efficient. Nonetheless, there is no known catalyst that can meet these criteria; that is why the development of new efficient catalysts will be essential for the development of the $\mathrm{CO}_{2}$ conversion process (Kuhl et al., 2014). In order to develop the new catalyst, more studies are needed on the various chemical reactions. The electrocatalysts provide decisive solutions to make the over potential lower and increase the selectivity as well as the kinetics of $\mathrm{CO}_{2}$ conversion reaction (Hossain, 2012).

During the last decades, several research studies were focused on the metal catalysts and the different products that were formed using these catalysts. There are four main classes of simple metal catalysts depending on the type of the products that are formed by the $\mathrm{CO}_{2}$ electrochemical reduction process (Hori, 2003; Jhong et al., 2013). This include $\mathrm{Cu}, \mathrm{Au}, \mathrm{Pb}$ and $\mathrm{Ni}$ to be used as electrodes in order to convert $\mathrm{CO}_{2}$ by electrochemical process to hydrocarbons, $\mathrm{CO}, \mathrm{HCOO}-$ and $\mathrm{H}_{2}$, receptively as shown in Fig. 6 .

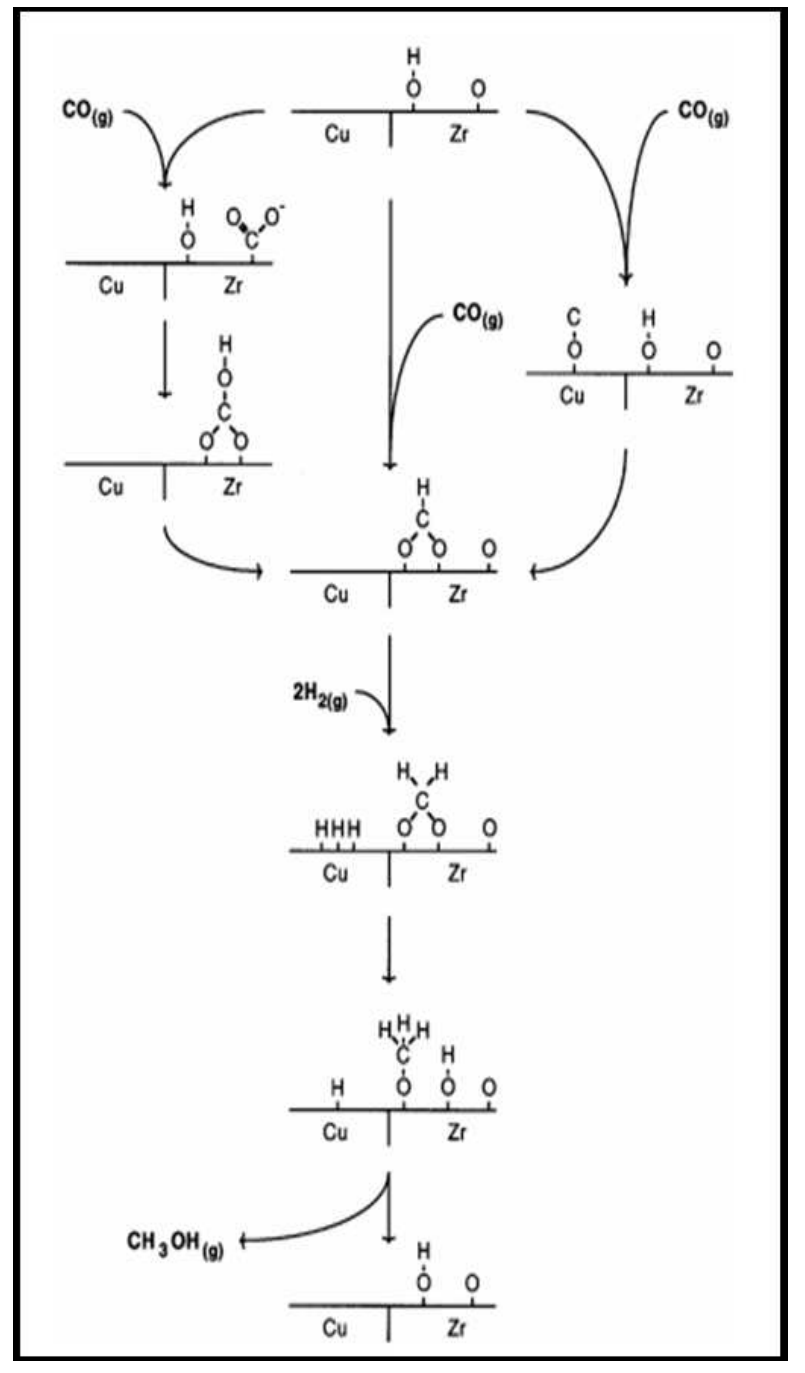

Fig. 4: The Mechanism of the Heterogeneous Catalytic Hydrogenation reduction of $\mathrm{CO}$ to Methanol on $\mathrm{Cu}-$ and $\mathrm{ZrO}_{2}$-containing catalysts (Fisher and Bell, 1998) 
A)

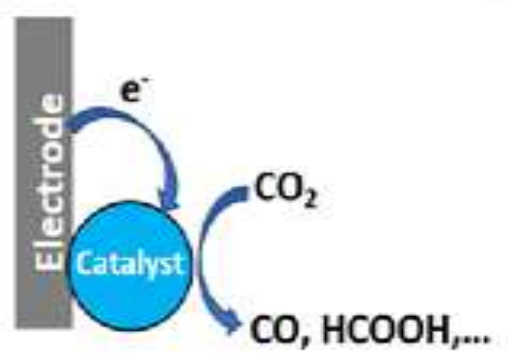

B)

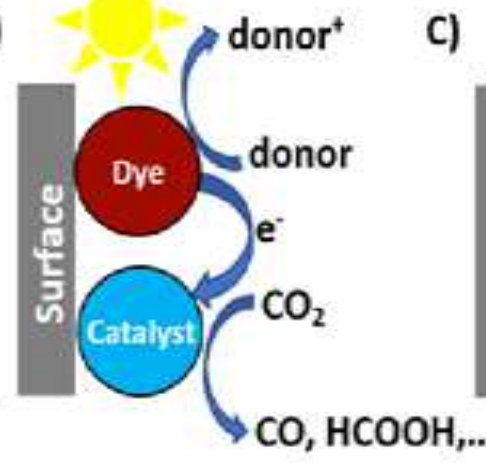

c)

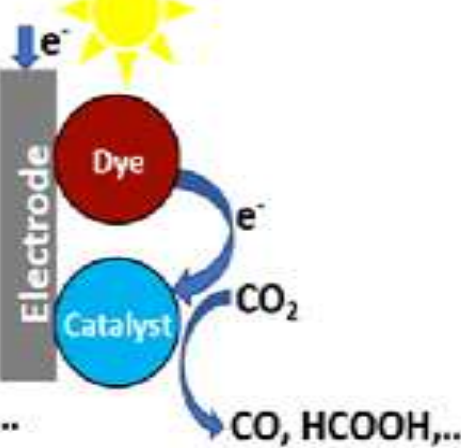

Fig. 5: Heterogeneous molecule systems: (A) Electrocatalysis, (B) Photocatalysis and (C) Photoelectrocatalysis (Windle and Reisner, 2015)

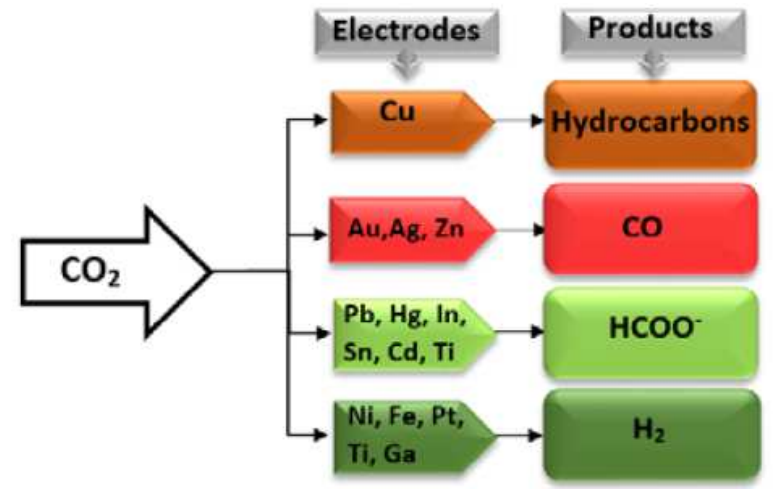

Fig. 6: Different electrode material and the reaction products of $\mathrm{CO}_{2}$ electrochemical reduction (Hori, 2003)

There are other products that can be formed by the metal catalysts such as oxalic acid and alcohol (Hori, 2003). Organometallic catalysts (Tornow et al., 2012), metal organic frameworks (Hinogami et al., 2012) and metal oxides (i.e., $\mathrm{Cu}_{2} \mathrm{O}$ ) (Chen et al., 2012; $\mathrm{Li}$ and Kanan, 2012) have been studied by some researchers within the last few years.

\section{Hydrocarbons}

A copper catalyst is considered to be the most suitable metal catalyst to convert $\mathrm{CO}_{2}$ to hydrocarbons at ambient temperature and pressure (Kuhl et al., 2012). Many different hydrocarbon products with their production mechanisms, through the use of $\mathrm{Cu}$ as a cathode in flow cell have been studied by Tang et al., (2012). Further, the copper surfaces show increase in the selectivity and make the over potential lower for hydrocarbon production processes (Kondratenko et al., 2013). Due to the abundance of the under-coordinated sites, the $\mathrm{Cu}$ electrode, which is covered by $\mathrm{Cu}$ nanoparticles, gives higher selectivity toward the $\mathrm{CO}_{2}$ conversion to hydrocarbons. Some researchers studied the modified $\mathrm{Cu}$ electrodes by annealing $\mathrm{Cu}$ foil in air, which resulted in a stable electrode that can make the overpotential lower for $\mathrm{CO}_{2}$ reduction by $0.5 \mathrm{~V}$ compared to polycrystalline $\mathrm{Cu}$ (Tang et al., 2012). Using two single crystal copper electrodes through two different mechanisms to produce ethylene, has been studied by Schouten et al. (2012):

$\mathrm{CO}_{2}+8 \mathrm{H}^{+}+8 e^{-} \rightarrow \mathrm{CH}_{4}+2 \mathrm{H}_{2} \mathrm{O}$

\section{Carbon Monoxide}

Gold, silver and zinc are the most metal catalysts used to adsorb $\mathrm{CO}$; it has been reported that the adsorbed $\mathrm{CO}$ is preventing more reduction of $\mathrm{CO}_{2}$, hence contributing in $\mathrm{H}_{2}$ production (Kondratenko et al., 2013). Diaminotriazole-based organometallic silver catalysts have been studied by Tornow et al. (2012), in which the gold loading has been decreased by a factor of around 20 by keeping the same performance. Interestingly, at this point, it is not clear if these organometallic silver species are considered as catalytically active species on the surface of electrode or not. The effect of the silver particle size on $\mathrm{CO}_{2}$ reduction has been investigated by Salehi-Khojin et al. (2013); they observed the maximum level of activity for the silver particle size of $5 \mathrm{~nm}$. Further, by reducing the gold oxide films, the gold nanoparticles are synthesized which are considered to have highly selectivity to reduce $\mathrm{CO}_{2}$ to CO (Chen et al., 2012):

$\mathrm{CO}_{2}+2 \mathrm{H}^{+}+2 e^{-} \rightarrow \mathrm{CO}+\mathrm{H}_{2} \mathrm{O}$

\section{Formic Acid}

Palladium and mercury are considered as the high efficiency metals to produce the formic acid. Further, other metals were found to be active for formic acid production process, such as MOF catalysts (Hinogami et al., 2012), alloys (Agarwal et al., 2011) and metal oxides (Chen and 
Kanan, 2012). The $\mathrm{Sn} / \mathrm{SnOx}$ metal/metal oxides catalyst is participating in the $\mathrm{CO}_{2}$ reduction methods, which the $\mathrm{Sn} / \mathrm{SnOx}$ catalyst shows higher efficiency for formic acid production while Sn0 is producing only hydrogen (Chen and Kanan, 2012). The pure Sn gives lower efficiency than the Sn-alloy at lower polarization (Agarwal et al., 2011). Furthermore, some results have been reported regarding the behavior of Copper Rubeanate Metal Organic Framework (CR MOF) catalyst (Inui et al., 1998). The results indicate that the (CR MOF) catalyst can make the onset for $\mathrm{CO}_{2}$ reduction lower by approximately $0.2 \mathrm{~V}$, compared to the plain copper electrode:

$$
\mathrm{CO}_{2}+2 \mathrm{H}^{+}+2 e^{-} \rightarrow \mathrm{HCOOH}
$$

The Gas Diffusion Electrodes (GDE) has been developed in order to improve the electrocatalytic cell (Agarwal et al., 2011). GDE consists of a Teflon-bonded carbon matrix where the metal particles are scattered. The applications of GDE for the $\mathrm{CO}_{2}$ electrocatalytic reduction process was studied by Mahmood et al. (1987) to convert $\mathrm{CO}_{2}$ to $\mathrm{HCOOH}$ at a current efficiency of $100 \%$ and a current density of $150 \mathrm{~mA} \mathrm{~cm} \mathrm{~cm}^{-2}$ with a potential of $-1.8 \mathrm{~V}$ versus the standard calomel electrode. An experiment was conducted on the platinum GDE, where the methane has been produced from $\mathrm{CO}_{2}$ at 30 bars and a Faradaic efficiency was around 34.8\% at a current density of $900 \mathrm{~mA} \mathrm{~cm}^{-2}$ (Hara et al., 1995).

\section{Methanol}

Methanol is considered as a valuable product while it has many different applications, it is manufactured as an intermediate to produce various chemicals (i.e., acetic acid and formaldehyde) (Olah et al., 2008). Recently, the formation of methanol from $\mathrm{CO}_{2}$ and $\mathrm{H}_{2}$ by electrochemical methods has been studied by several researchers (Le et al., 2011). Hence, the results obtained were as follows, the reduction of $\mathrm{CO}_{2}$ to methanol process accomplish low efficacy and/or low current densities, while both have to be high for the commercial process. The direct electrochemical reduction of $\mathrm{CO}_{2}$ to methanol reaction is kinetically a little bit complex and requires an effective electrocatalysts (Olah et al., 2008; Wang et al., 2015):

$$
\mathrm{CO}_{2}+6 \mathrm{H}^{+}+2 e^{-} \rightarrow \mathrm{CH}_{3} \mathrm{OH}+\mathrm{H}_{2} \mathrm{O}
$$

Some experiments have been conducted on the single crystal $\mathrm{Cu}$ electrodes, where the various surface faces show different selectivity and activity in $\mathrm{CO}_{2}$ electrocatalytic reduction process. Single crystal of copper electrodes have been controlled by $\mathrm{Cu}(100)$ faces favour $\mathrm{C}_{2} \mathrm{H}_{4}$ formation, while the other types which is controlled by $\mathrm{Cu}(111)$ faces show better selectivity towards $\mathrm{CH}_{4}$ (Hori et al., 2003).

Other researchers conducted an experiment with lowdensity energy cell, which is used to convert $\mathrm{CO}_{2}$ and $\mathrm{H}_{2}$ to methanol at ambient pressure with current efficiency up to $97 \%$ and a potential of $-0.1 \mathrm{~V}$ versus the standard hydrogen electrode (Kobayashi and Takahashi, 2004).

\section{Ethanol}

Ren et al. (2016) conducted an experiment, using a prepared series of oxide-derived CuxZn catalysts (i.e., $\mathrm{Cu}_{10} \mathrm{Zn}, \mathrm{Cu}_{4} \mathrm{Zn}$ and $\mathrm{Cu}_{2} \mathrm{Zn}$ ) in order to improve the conversion of $\mathrm{CO}_{2}$ to ethanol by electroreduction process. Further, it was proved that $\mathrm{CO}_{2}$ will be reduced more preferentially on metallic compared to the oxide surfaces. However, the selectivity of ethanol production versus ethylene has been discovered by defining the ratio of their Faradaic efficiencies (FEethanol/FEethylene); the ratio can be tuned by the factor of 12.5 by changing the amount of $\mathrm{Zn}$ in the CuxZn catalysts. The maximum ethanol production has been achieved by using $\mathrm{Cu}_{4} \mathrm{Zn}$ at $-1.05 \mathrm{~V}$ at a Faradaic efficiency of $29.1 \%$ with a partial current density of -8.2 $\mathrm{mA} \mathrm{cm}{ }^{-2}$. Ren et al. (2016) studied the conversion of $\mathrm{CO}_{2}$ to n-propanol $\left(\mathrm{CH}_{3} \mathrm{CH}_{2} \mathrm{CH}_{2} \mathrm{OH}\right)$ through the electrocatalytic process by using mass of around $15 \mathrm{~nm}$ sized copper nanocrystals in an aqueous $0.1 \mathrm{M} \mathrm{KHCO}_{3}$. In which the onset potential was within the range between 200 to $300 \mathrm{mV}$ for the n-propanol formation, which is more positively than for $\mathrm{CuO}$ nanoparticles or electropolished $\mathrm{Cu}$ surface. The production of this cell is n-propanol at a potential of $-0.95 \mathrm{~V}$ versus the reversible hydrogen electrode where the total current density was $-1.74 \mathrm{~mA} \mathrm{~cm}{ }^{-2}$, which is much larger, compared to the one that found on $\mathrm{CuO}$ nanoparticles at the same conditions (Ren et al., 2016).

\section{Synthesis Gas}

The conversion of $\mathrm{CO}_{2}$ into synthesis gas in a cell that employs $\mathrm{Ni}$ /active carbon fibre and $\mathrm{Cu} /$ metal oxide GDEs was studied by Kohno et al. (2001b). Many cells for the production of synthesis gas from $\mathrm{CO}_{2}$ by electrocatalytic process have been studied during the last few years. For example, different cell designs have been tested by Delacourt et al. (2008) which are based on Proton Exchange Membrane Fuel Cells (PEMFCs) for the conversion of $\mathrm{CO}_{2}$ and $\mathrm{H}_{2} \mathrm{O}$ to synthesis gas. The best results were found when the enhanced PEMFC is used, which can be modified by adding a glass fibre supported layer of the aqueous $\mathrm{KHCO}_{3}$ between the proton-exchange membrane (Nafion). The production of this cell is a synthesis gas at a potential of $-2 \mathrm{~V}$ versus the standard calomel electrode where the total current density was $80 \mathrm{~mA} \mathrm{~cm}^{-2}$ at $25^{\circ} \mathrm{C}$. 
Table 2 summarizes the different electrocatalyst systems (i.e., $\mathrm{Au}_{25}, \mathrm{Au}$-oxide $\mathrm{NPs}, \mathrm{Ag}, \mathrm{SnO}_{2}$, etc.) which are used to convert one tonne $\mathrm{CO}_{2}$ into various products such as carbon monoxide, formic acid, ethylene, methane and methanol with the energy requirements in $\mathrm{MWh}$ /tonne $\mathrm{CO}_{2}$ by assuming $500 \mathrm{mV}$ overpotential for anodic OER and all voltages are in the RHE scale (Kauffman et al., 2015).

\section{Photocatalytic $\mathrm{CO}_{2}$ Reduction}

The photocatalytic $\mathrm{CO}_{2}$ reduction method converts the $\mathrm{CO}_{2}$ to valuable products, such as methane and methanol, by using solar energy (i.e., light or laser) (Fig. 5B) (Fan et al., 2013; Hossain, 2012). During the past few years, this method has been considered as the most attractive method for $\mathrm{CO}_{2}$ reduction. The photocatalytic conversion process is a complex combination of photochemical and photophysical processes (Fan et al., 2013). The artificial photoconversion for $\mathrm{CO}_{2}$ utilization (Fig. 7) presents a challenge to the hydrogenation process which requires $\mathrm{H}_{2}$ (Arakawa et al., 2001).

In general, the photocatalysis process to reduce $\mathrm{CO}_{2}$ with $\mathrm{H}_{2} \mathrm{O}$ involve three main steps (Xie et al., 2016) (Fig. 8). Generating electron-hole pairs is done in the first step when the semiconductor is supported by an appropriate light/laser source, which has energy greater than, or equal to the band-gap Energy (Eg) of the semiconductor. Then, the generated electronsholes transfer to the surface of the semiconductor in the second step as shown in Fig. 8. After that, large fraction of electron-hole pairs will recombined together with the energy being released in the form of heat or photons. $\mathrm{CO}_{2}$ will be reduced by the generated electrons into $\mathrm{HCOOH}, \mathrm{CH}_{4}, \mathrm{CH}_{3} \mathrm{OH}$, or $\mathrm{CO}$ and $\mathrm{H}_{2} \mathrm{O}$ will be oxidized by the holes to $\mathrm{O}_{2}$ in the third step.

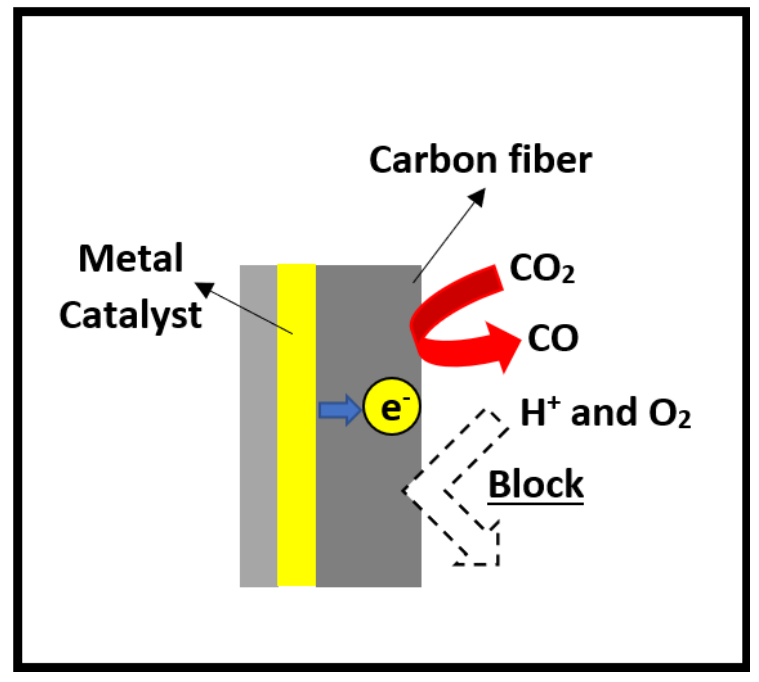

Fig. 7: $\mathrm{CO}_{2}$ utilization by artificial photoconversion (Sato et al., 2016)

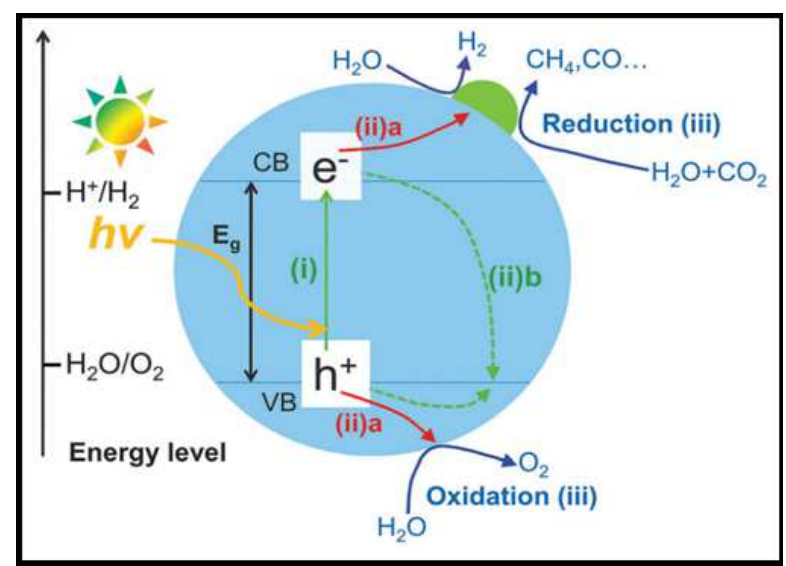

Fig. 8: The basic mechanism of $\mathrm{CO}_{2}$ photocatalytic

Table 2: Energy needed and Faradaic efficiency for selected catalyst systems to convert 1 tonne $\mathrm{CO}_{2}$ in to different products

\begin{tabular}{|c|c|c|c|c|}
\hline Electrocatalyst & Product & $\begin{array}{l}\text { Faradaic } \\
\text { efficiency }\end{array}$ & $\begin{array}{l}\text { Energy needed } \\
\left(\mathrm{MWh} / \text { tonne } \mathrm{CO}_{2}\right)\end{array}$ & References \\
\hline$\overline{\mathrm{Au}_{25}}$ & Carbon monoxide & $99 \%$ & 3.36 & (Kauffman et al., 2014; 2012) \\
\hline Au-oxide NPs & & $99 \%$ & 2.74 & (Chen et al., 2012) \\
\hline $\mathrm{Cu}$-oxide NPs & & $61 \%$ & 5.45 & (Kauffman et al., 2011) \\
\hline $\mathrm{Ag}$ & & $99 \%$ & 3.08 & (Rosen et al., 2011) \\
\hline $\mathrm{Cu}$-oxide & Carbon monoxide + & $69 \%$ & 3.94 & (Li and Kanan, 2012) \\
\hline $\mathrm{SnO}_{2}$ & Formic acid & $99 \%$ & 2.99 & (Chen and Kanan, 2012) \\
\hline $\mathrm{SnO}_{2} \mathrm{NPs}$ & Formic acid & $86 \%$ & 4.72 & (Zhang et al., 2014) \\
\hline $\mathrm{PbO}_{2}$ & & $100 \%$ & 3.02 & (Lee and Kanan, 2014) \\
\hline $\mathrm{Cu}$ & Ethylene & $48 \%$ & 42.28 & (Qiao et al., 2014) \\
\hline $\mathrm{Cu}$ & & $50 \%$ & 38.84 & (Gattrell et al., 2006) \\
\hline $\mathrm{Cu}$ NPs & Methane & $77 \%$ & 19.50 & (Manthiram et al., 2014) \\
\hline $\mathrm{Cu}$ & & $72 \%$ & 18.74 & (Peterson and Nørskov, 2012) \\
\hline Mo & Methanol & $50 \%$ & 15.40 & (Qiao et al., 2014) \\
\hline $\mathrm{Cu}$-oxide & & $40 \%$ & 21.50 & (Qiao et al., 2014) \\
\hline $\mathrm{RuO}_{2}$ & & $60 \%$ & 14.20 & (Herron et al., 2015) \\
\hline $\mathrm{RuO}_{2}-\mathrm{TiO}_{2}$ & & $50 \%$ & 17.00 & (Qiao et al., 2014) \\
\hline
\end{tabular}


The chemical reductant is required for the photocatalytic reactions, where these reactions do not include any electrical wiring to reduce the oxidized semiconductor or photocatalyst (Windle and Reisner, 2015). Some researchers studied the use of transitionmetals oxide as both solar energy converters and photocatalysts and the reasons are that their absorption properties of the solar spectrum and they can be excited for long time (Arakawa et al., 2001). There are many different semiconductor systems for the $\mathrm{CO}_{2}$ photoreduction, but the most commonly used systems are the semiconducting material systems which consist mainly of $\mathrm{TiO}_{2}$ (Wang et al., 2014). It has been reported that the advantages of $\mathrm{TiO}_{2}$ semiconductor, such as, its high availability with comparatively low cost, low toxicity and it has good resistance to the photo-indicate corrosion (Indrakanti et al., 2009).

\section{$\mathrm{TiO}_{2}$-Related Photocatalysts}

\section{$\mathrm{TiO}_{2}$ Nanomaterials}

Semiconductors Nanoparticles (NPs) were the result of some improvements that have been made on the semiconductor powders systems (e.g., $\mathrm{TiO}_{2}$ suspended in a beaker of water). Using the $\mathrm{TiO}_{2}$ NPs systems increases the surface area of the used catalysts, which leads to an increase in the frequency between $\mathrm{TiO}_{2}$ and $\mathrm{CO}_{2}$ (Wang et al., 2014). $\mathrm{P}_{25}$ is considered as a widely available source for the anatase-rutile mixed phase $\mathrm{TiO}_{2}$ NPs which can be used in photocatalytic research; due to its valuable properties, such as high catalytic activity (Hurum et al., 2003). It has been proved that the $\mathrm{TiO}_{2}$ crystal structure and morphology studies are one of the methods that can contribute in increasing the $\mathrm{TiO}_{2}$ photocatalytic activity ( $\mathrm{Xu}$ et al., 2013). A good example to explain the crystal structure effect has been studied by $\mathrm{Xu}$ et al. (2013) which is the $\mathrm{TiO}_{2}$ nanosheets with $95 \%$ exposed (100) facet where the maximum photocatalytic activity was achieved. The electron which is transferring through the $\mathrm{TiO}_{2}$ can be controlled by changing the morphology of the $\mathrm{TiO}_{2}$. The porous microspheres of MgO-ptched $\mathrm{TiO}_{2}$ is the most studied morphology as mentioned by Liu et al. (2013). The anatase phase nanorods which is modified with rutile phase $\mathrm{NPs}_{\mathrm{S}}\left(\mathrm{TiO}_{2}{ }^{-}\right.$ RMR) has been studied by Wang et al. (2012a) in which $\mathrm{TiO}_{2}$-RMR showed higher conversion rate compared to the just anatase phase nanorods.

\section{$\mathrm{TiO}_{2}$ Crystal Structure}

Many researches have been conducted in order to see the effect of the $\mathrm{TiO}_{2}$ crystal structure on the activity of photocatalysts (Pan et al., 2011). Anatase, brookite and rutile are the crystal forms of $\mathrm{TiO}_{2}$. The best studied and understood crystal phases are anatase and rutile, where the brookite is the least studied (Liu et al., 2012). The optimum composition for an anatase-brookite photocatalyst for the reduction of $\mathrm{CO}_{2}$ has been reported by Zhao et al. (2013), where the obtained results show that the anatase-brookite system, which consists of $75 \%$ anatase and $25 \%$ brookite showed the maximum photocatalytic activity.

\section{$\mathrm{TiO}_{2}$ in Mesoporous Support}

It has been proved that the photocatalytic activity can be increased by incorporating a mesoporous support (i.e., $\mathrm{SiO}_{2}$ ) into $\mathrm{TiO}_{2}$ lattices (Anpo et al., 1998). Furthermore, the $\mathrm{SiO}_{2}$ mesoporous network contributes in increasing the surface area of the system for $\mathrm{CO}_{2}$ to be reduced. A rapid and low-cost synthesis method has been studied using the Furnace Aerosol Reactor (FuAR) in order to synthesize the $\mathrm{Cu}-\mathrm{TiO}_{2}-\mathrm{SiO}_{2}$ photocatalyst composite particles that can be formed by evaporation driven selfassembly (Wang et al., 2011).

Table 3 and Fig. 9 summarize the different semiconductors used in the $\mathrm{CO}_{2}$ photoreduction process; Table 3 shows the products that can be formed by using these semiconductors and the $\mathrm{CO}_{2}$ conversion in $(\mu \mathrm{mol} / \mathrm{g})$. The most common products in the $\mathrm{CO}_{2}$ photoreduction system are $\mathrm{CO}$ and $\mathrm{HCOOH}$, where the reactions need only 2 electrons and 2 protons. It is generally difficult to form the other products, such as ethanol, formaldehyde, methanol and methane, in the gas-solid systems. The reason is that these formation reactions need more electrons and protons; however, the reactions are thermodynamically favorable. Some other products can by formed by a series of different reactions, such as $\mathrm{CH}_{4}$ (Roy et al., 2010; Varghese et al., 2009; Wang et al., 2014):

$$
\begin{aligned}
& \mathrm{CO}_{2}+2 \mathrm{H}^{+}+2 e^{-} \rightarrow \mathrm{CO}+\mathrm{H}_{2} \mathrm{O} \\
& \mathrm{CO}_{2}+6 \mathrm{H}^{+}+6 e^{-} \rightarrow \mathrm{CH}_{3} \mathrm{OH}+\mathrm{H}_{2} \mathrm{O} \\
& \mathrm{CO}+6 \mathrm{H}^{+}+6 e^{-} \rightarrow \mathrm{CH}_{4}+\mathrm{H}_{2} \mathrm{O} \\
& \mathrm{CH}_{3} \mathrm{OH}+2 \mathrm{H}^{+}+2 e^{-} \rightarrow \mathrm{CH}_{4}+\mathrm{H}_{2} \mathrm{O}
\end{aligned}
$$

Other photocatalysts can be used to form methanol such as noble metals (i.e., $\mathrm{Pt}, \mathrm{Pd}, \mathrm{Ru}$ and $\mathrm{Rh}$ ) and copper based catalysts (i.e., $\mathrm{Cu} / \mathrm{ZnO}$ catalyst with modifiers); the advantages and disadvantages of these processes are shown in (Table 4) (Li et al., 2014; Wang et al., 2015).

\section{Photoelectrocatalytic $\mathrm{CO}_{2}$ Reduction}

The photoelectrocatalytic $\mathrm{CO}_{2}$ reduction method is combining the electrocatalytic and photocatalytic methods together (Fig. 5C). Thus, it means that the electrochemical $\mathrm{CO}_{2}$ conversion process is using the light as the source of energy and the semiconductor (e.g., $\mathrm{GaP}, \mathrm{SiC})$ as the cathode, where the electrons are 
receiving from the anode (Chang et al., 2009; Windle and Reisner, 2015). Fig. 10 presents the different twocompartment photoelectrocatalytic cells which are separated by proton exchange membranes for the reduction of $\mathrm{CO}_{2}$ (Xie et al., 2016). Semiconductor can be used as photocathode (Fig. 10A) or photoanode (Fig. 10B). Semiconductor can be used as both photocathode and photoanode (Fig. 10C) where the light will be absorbed by both electrodes in order to generate electrons and holes pairs. The photoelectrochemical approach has many benefits in term of space and cost saving, where the electrochemical system in combining with the solar collection process without reducing the performance of both systems (Hossain, 2012).

Table 3: $\mathrm{CO}_{2}$ photoreduction by different semiconductors

\begin{tabular}{|c|c|c|c|}
\hline Semiconductor systems & Product & $\mathrm{CO}_{2}$ Conversion $(\mu \mathrm{mol} / \mathrm{g})$ & References \\
\hline $\mathrm{Pt} \mathrm{NP} / \mathrm{TiO}_{2}$ film & Methane & 1361.00 & (Wang et al., 2012b) \\
\hline $\mathrm{TiO}_{2}-\mathrm{RMA}$ & & 2.40 & (Wang et al., 2012a) \\
\hline $\mathrm{Cu}-\mathrm{TiO}_{2}$ dye sensitized & & 0.30 & (Yuan et al., 2012) \\
\hline Pt loaded c- $\mathrm{NaNbO}_{3}$ & & 4.86 & (Li et al., 2012) \\
\hline $\mathrm{TiO}_{2}(\mathrm{P}-25)$ & & 0.43 & (Kaneco et al., 1998) \\
\hline $\mathrm{Cu} / \mathrm{TiO}_{2} / \mathrm{SiO}_{2}$ (wet method) & Carbon monoxide & 45.00 & (Li et al., 2010) \\
\hline $\mathrm{Cu} / \mathrm{TiO}_{2} / \mathrm{SiO}_{2}$ (aerosol method) & & 20.00 & (Wang et al., 2011) \\
\hline $\mathrm{MgO}$ & & 4.00 & (Kohno et al., 2001a) \\
\hline $\mathrm{ZrO}_{2}$ & & 5.00 & (Kohno et al., 2000) \\
\hline Anatase $(75 \%)$ brookite( $25 \%)$ & & 2.10 & (Zhao et al., 2013) \\
\hline $\mathrm{TiO}_{2} / \mathrm{GO}$ layered sheets & Methane/Carbon monoxide & 10.00 & (Tu et al., 2012) \\
\hline $\mathrm{Rh}-\mathrm{TiO}_{2}$ & & 5.20 & (Kohno et al., 1999) \\
\hline $\mathrm{Cu}-\mathrm{TiO}_{2}$ & Methanol & 20.00 & (Tseng et al., 2004) \\
\hline $\mathrm{TiO}_{2} /$ zeolite & & 13.00 & (Yamashita et al., 1998) \\
\hline $\mathrm{Cu} / \mathrm{Fe}-\mathrm{TiO}_{2}-\mathrm{SiO}_{2}$ & & 4.12 & (Wu, 2009) \\
\hline $\mathrm{TiO}_{2}$ powder & Formic acid & 1.80 & (Kaneco et al., 1999) \\
\hline $\mathrm{CoPc}_{-} \mathrm{TiO}_{2}$ & Formic acid/Methane & 33.50 & (Liu et al., 2007) \\
\hline Nafion layer on $\mathrm{Pd}-\mathrm{TiO}_{2}$ & Methane/Ethane & 3.30 & (Kim et al., 2012) \\
\hline
\end{tabular}

Table 4: Advantages and disadvantages of different photocatalysts

\begin{tabular}{|c|c|c|c|}
\hline Catalyst & Advantages & Disadvantages & References \\
\hline $\begin{array}{l}\text { Noble metals (i.e., Pt, Pd, } \\
\text { Ru and } R h \text { ) }\end{array}$ & $\begin{array}{l}\text { Resisted to coking } \\
\text { High activity }\end{array}$ & High cost & (Li et al., 2014) \\
\hline $\begin{array}{l}\text { Copper based catalysts (i.e., } \mathrm{Cu} / \mathrm{ZnO} \\
\text { catalyst with modifiers, such as } \mathrm{Si}, \mathrm{Ga} \text {, etc.) }\end{array}$ & $\begin{array}{l}\text { Low cost } \\
\text { Good thermal stability }\end{array}$ & Low activity & (Gawande et al., 2016) \\
\hline
\end{tabular}

Table 5: Photoelectrocatalytic systems reported for the reduction of $\mathrm{CO}_{2}$

\begin{tabular}{|c|c|c|c|}
\hline Electrode & Product amounts, concentrations or rates & References & \\
\hline (1) No co-catalyst & $\begin{array}{l}\text { Photocathode: } \mathrm{p}-\mathrm{GaP} \\
\text { Anode: carbon rod }\end{array}$ & $\begin{array}{l}\text { HCOOH: } 50 \mathrm{mM} \\
\mathrm{HCHO}: 0.28 \mathrm{mM} \\
\mathrm{CH}_{3} \mathrm{OH}: 0.81 \mathrm{mM}\end{array}$ & (Halmann, 1978) \\
\hline \multirow[t]{2}{*}{$\begin{array}{l}\text { (2) Metal complex } \\
\text { co-catalyst }\end{array}$} & $\begin{array}{l}\text { Photocathode: } \\
\text { Ru complex modified Zn-doped p-InP } \\
\text { Anode: Glassy carbon }\end{array}$ & HCOOH: $0.17 \mathrm{mM}$ & (Arai et al., 2010) \\
\hline & $\begin{array}{l}\text { Photocathode: } \mathrm{Ru} \text { complex } \\
\text { polymer modified } \mathrm{Cu}_{2} \mathrm{ZnSnS}_{4} \\
\text { Anode: glassy carbon }\end{array}$ & HCOOH: $0.49 \mathrm{mM}$ & (Arai et al., 2011) \\
\hline \multirow[t]{4}{*}{$\begin{array}{l}\text { (3) One-or two-dimensional } \\
\text { nanostructure photoelectrode }\end{array}$} & $\begin{array}{l}\text { Photocathode: polypyrrole-coated p-ZnTe } \\
\text { Anode: Carbon rod }\end{array}$ & $\begin{array}{l}\mathrm{HCOOH}: 131, \mathrm{CO}: 50 \\
\mathrm{H}_{2}: 108 \mathrm{nmol} \mathrm{h}^{-1} \mathrm{~cm}^{-2}\end{array}$ & (Chung et al., 2016) \\
\hline & $\begin{array}{l}\text { Photocathode: } \mathrm{ZnTe} / \mathrm{ZnO} \\
\text { nanowire/Zn substrate } \\
\text { Anode: } \mathrm{Pt} \text { electrode }\end{array}$ & CO: $68 \mathrm{mmol} \mathrm{cm}{ }^{-2}$ & (Jang et al., 2016) \\
\hline & $\begin{array}{l}\text { Photocathode: } \mathrm{Cu} / \mathrm{Cu}_{2} \mathrm{O} \text { electrode } \\
\text { Anode: Pt electrode }\end{array}$ & $\begin{array}{l}\mathrm{CH}_{3} \mathrm{OH}: 178 \mathrm{ppm} \\
\mathrm{HCHO}: 10 \mathrm{ppm}\end{array}$ & (de Brito et al., 2015) \\
\hline & $\begin{array}{l}\text { Photocathode: } \mathrm{Cu} \text { nanoparticles-doped } \\
\mathrm{Co}_{3} \mathrm{O}_{4} \text { nanotube arrays } \\
\text { Anode: } \text { Pt electrode }\end{array}$ & HCOOH: $6.8 \mathrm{mmol} \mathrm{L}^{-1} \mathrm{~cm}^{-2}$ & (Shen et al., 2015) \\
\hline
\end{tabular}




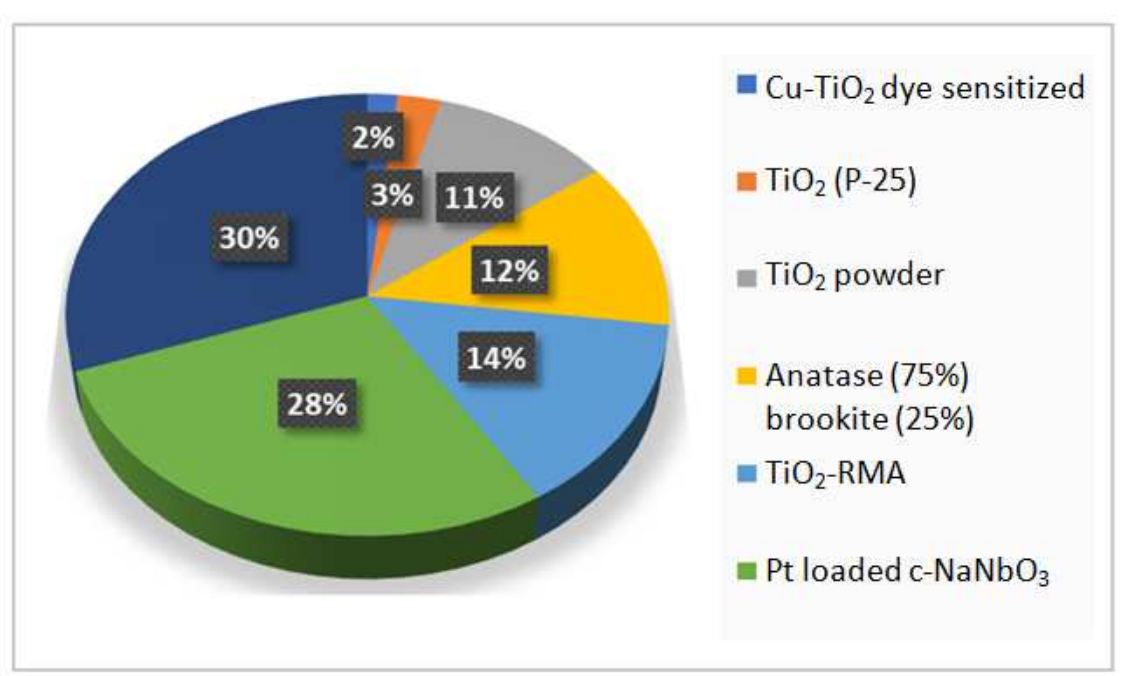

Fig. 9: $\mathrm{CO}_{2}$ Conversion $(\mu \mathrm{mol} / \mathrm{g})$ by different semiconductors (Kaneco et al., 1999, 1998; Kohno et al., 1999; Li et al., 2012; Wang et al., 2012a; Yuan et al., 2012; Zhao et al., 2013)

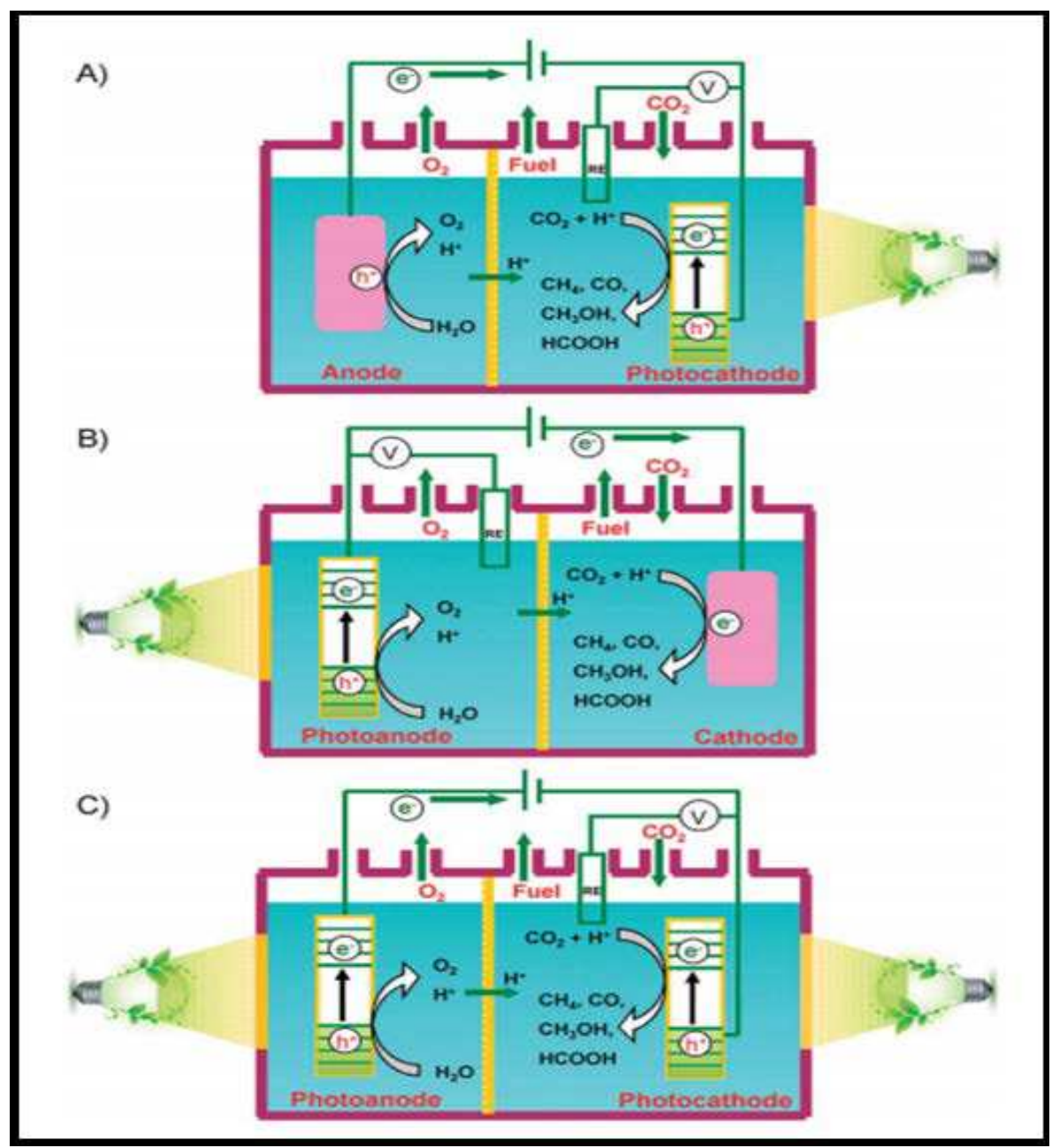

Fig. 10: The different two-compartment photoelectrocatalytic cells for the reduction of $\mathrm{CO}_{2}$; (A) Semiconductors as photocathodes; (B) Semiconductors as photoanodes; (C) Semiconductors as both photoanodes and photocathodes (Xie et al., 2016) 
The layer-by-layer structure has been studied by Windle and Reisner (2015) where the process of photoelectro-catalytic $\mathrm{CO}_{2}$ reduction can be achieved. The first layer consists of dye which can be either molecular or a semiconducting material, this layer absorbs the visible light and the electrons are transferred directly to the catalyst and the oxidized dye is regenerated by hole transfer to the semiconductor. It has been mentioned that the calcium copper titanium oxide $\mathrm{CaCu}_{3} \mathrm{Ti}_{4} \mathrm{Ol}_{2}$ (CCTO), is considered as a best example of photoelectro-catalyst in which it shows excellent Photoelectrochemical (PEC) ability (Kushwaha et al., 2016). Table 5 summarizes some recently reported systems with the three different types of photoelectrocatalytic cells for the $\mathrm{CO}_{2}$ reduction.

\section{Barriers and Challenges for Future Prospective}

The poor product selectivity and the high/low reaction temperatures are considered to be the main barriers in the heterogeneous $\mathrm{CO}_{2}$ reduction process. For example, the suitable catalysts are needed for the conversion of $\mathrm{CO}_{2}$ to methanol at lower reaction temperatures.

Further, many barriers exist in the $\mathrm{CO}_{2}$ electrocatalysis reduction, in which the electrocatalysts are needed to be used at lower over potentials with higher selectivity. Many different heterogeneous electrocatalysts which are selective, fast and energy-efficient are known, but they are unstable. Photochemical processes can offer an attractive approach for $\mathrm{CO}_{2}$ reduction using solar energy. However, this method is not widely used because it needs a critical condition to absorb the required amount of solar energy. In general, some of barriers still exist and make the improvements of $\mathrm{CO}_{2}$ utilization technologies slower, such as:

- Compared to the other energy-related technologies

- $\mathrm{CO}_{2}$ utilization technology is much less supported.

- Fossil fuel plants still get benefits currently by energy regulations

- $\mathrm{CO}_{2}$ utilization processes that contribute to $\mathrm{CO}_{2}$ reduction at commercial scale are yet to be demonstrated

Therefore, more researches are necessary in order to improve the effective $\mathrm{CO}_{2}$ utilization technologies, to make more advances in heterogeneous catalysts for $\mathrm{CO}_{2}$ reduction process and to apply various approaches in the effective catalytic $\mathrm{CO}_{2}$ conversion.

\section{Summary and Future Outlook}

$\mathrm{CO}_{2}$ reduction is presenting both an opportunity and a challenge worldwide for sustainability of environment and energy. The main strategies of $\mathrm{CO}_{2}$ reduction should focus on the utilization of $\mathrm{CO}_{2}$, such as the use of $\mathrm{CO}_{2}$ for the environmental processes, the $\mathrm{CO}_{2}$ recycling combined with the renewable energy to save carbon sources and the production of useful chemicals from $\mathrm{CO}_{2}$. The conversion of $\mathrm{CO}_{2}$ into useful chemicals such as cyclic carbonates and urea is promising and will reduce $\mathrm{CO}_{2}$ emissions into the atmosphere. In order to achieve a high performance in the $\mathrm{CO}_{2}$ conversion process, the development of reduction reactions and using an effective catalyst are required. However, it should be noted that the amount of generated useful chemicals is not that enough to consume all the captured $\mathrm{CO}_{2}$ which means that other solutions should be taken into consideration in order to get rid of all captured $\mathrm{CO}_{2}$. On the hand, the conversion of $\mathrm{CO}_{2}$ into energy product such as DMC, methanol and DME, will consume larger amount of captured $\mathrm{CO}_{2}$ where the reason is that the market scale is potentially extensive. Furthermore, the generated energy products can be used instead of the fossil fuel, thus reducing the dependence on fossil fuel and contribute in the market growth of $\mathrm{CO}_{2}$ utilization. There are many challenges in the catalytic $\mathrm{CO}_{2}$ utilization where it requires a huge amount of used catalysts and specific conditions, such as high pressure, high temperature and long time for the reaction because of chemically stable $\mathrm{CO}_{2}$. Therefore, restrains the process in a laboratory scale with low conversion. Furthermore, the design of catalytic materials, which are featuring high product stability, selectivity and a composition of earth-abundant elements is one of the major challenges that face $\mathrm{CO}_{2}$ utilization.

\section{Acknowledgement}

The authors would like to acknowledge the financial support of Qatar University in terms of a Graduate Assistantship to Sajeda Alsaydeh. They also acknowledge the continuous support provided by the Advanced Material (CAM) and the Gas Processing Center (GPC).

\section{Author's Contributions}

Sajeda A. Al-Saydeh: She made considerable contributions to carrying out the literature review. Furthermore, she prepared the initial draft of the manuscript.

Syed J. Zaidi: He made considerable contributions to designing the research plan. In addition, he supervised the research work and revised the draft of the manuscript.

Muftah H. El-Naas: He made considerable contributions to designing the research plan. In addition, he revised the draft of the manuscript.

\section{Ethics}

This paper is original and includes unpublished materials. The corresponding author authorizes that the 
other authors have read and approved the manuscript and there is no ethical issues involved.

\section{References}

Agarwal, A.S., Y. Zhai, D. Hill and N. Sridhar, 2011. The electrochemical reduction of carbon dioxide to formate/formic acid: Engineering and economic feasibility. ChemSusChem, 4: 1301-1310.

DOI: $10.1002 /$ cssc. 201100220

USEIA, 2016. United States Energy Information Administration

Anpo, M., H. Yamashita, K. Ikeue, Y. Fujii and S.G. Zhang et al., 1998. Photocatalytic reduction of $\mathrm{CO}_{2}$ with $\mathrm{H}_{2} \mathrm{O}$ on Ti-MCM-41 and Ti-MCM-48 mesoporous zeolite catalysts. Catalysis Today, 44: 327-332.

DOI: $10.1016 / \mathrm{S} 0920-5861(98) 00206-5$

Arai, T., S. Sato, K. Uemura, T. Morikawa and T. Kajino et al., 2010. Photoelectrochemical reduction of $\mathrm{CO}_{2}$ in water under visible-light irradiation by a p-type InP photocathode modified with an electropolymerized ruthenium complex. Chem. Commun., 46: 6944-6946.

DOI: $10.1039 / \mathrm{C} 0 \mathrm{CC} 02061 \mathrm{C}$

Arai, T., S. Tajima, S. Sato, K. Uemura and T. Morikawa et al., 2011. Selective $\mathrm{CO}_{2}$ conversion to formate in water using a CZTS photocathode modified with a ruthenium complex polymer. Chem. Commun., 47: 12664-12666.

DOI: $10.1039 / \mathrm{C} 1 \mathrm{CC} 16160 \mathrm{~A}$

Arakawa, H., M. Aresta, J.N. Armor, M.A. Barteau and E.J. Beckman et al., 2001. Catalysis research of relevance to carbon management: Progress, challenges and opportunities. Chem. Rev., 101: 953-996. DOI: $10.1021 / \mathrm{cr} 000018 \mathrm{~s}$

Aresta, M. and A. Dibenedetto, 2003. Carbon dioxide fixation into organic compounds, Carbon Dioxide Recovery and Utilization. Springer.

Aresta, M. and I. Tommasi, 1997. Carbon dioxide utilisation in the chemical industry. Energy Convers. Manage., 38: S373-S378. DOI: 10.1016/S0196-8904(96)00297-X

Benson, E.E., C.P. Kubiak, A.J. Sathrum and J.M. Smieja, 2009. Electrocatalytic and homogeneous approaches to conversion of $\mathrm{CO}_{2}$ to liquid fuels. Chem. Society Rev., 38: 89-99. DOI: 10.1039/B804323J

Centi, G. and S. Perathoner, 2009. Opportunities and prospects in the chemical recycling of carbon dioxide to fuels. Catalysis Today, 148: 191-205. DOI: 10.1016/j.cattod.2009.07.075

Chang, T.Y., R.M. Liang, P.W. Wu, J.Y. Chen and Y.C. Hsieh, 2009. Electrochemical reduction of $\mathrm{CO}_{2}$ by $\mathrm{Cu}_{2} \mathrm{O}$-catalyzed carbon clothes. Mater. Lett., 63: 1001-1003. DOI: 10.1016/j.matlet.2009.01.067
Chen, Y. and M.W. Kanan, 2012. Tin oxide dependence of the $\mathrm{CO}_{2}$ reduction efficiency on tin electrodes and enhanced activity for tin/tin oxide thin-film catalysts. J. Am. Chem. Society, 134: 1986-1989. DOI: $10.1021 /$ ja2108799

Chen, Y., C.W. Li and M.W. Kanan, 2012. Aqueous $\mathrm{CO}_{2}$ reduction at very low overpotential on oxidederived Au nanoparticles. J. Am. Chem. Society, 134: 19969-19972. DOI: 10.1021/ja309317u

Chung, J., J. Koh, E.H. Kim and S.I. Woo, 2016. Hierarchical $\mathrm{Cu}$ pillar electrodes for electrochemical $\mathrm{CO}_{2}$ reduction to formic acid with low overpotential. Phys. Chem. Chemical Phys., 18: 6252-6258. DOI: $10.1039 / \mathrm{C} 5 \mathrm{CP} 07964 \mathrm{~K}$

de Brito, J.F., A.R. Araujo, K. Rajeshwar and M.V.B. Zanoni, 2015. Photoelectrochemical reduction of $\mathrm{CO}_{2}$ on $\mathrm{Cu} / \mathrm{Cu}_{2} \mathrm{O}$ films: Product distribution and $\mathrm{pH}$ effects. Chem. Eng. J., 264: 302-309.

DOI: 10.1016/j.cej.2014.11.081

Delacourt, C., P.L. Ridgway, J.B. Kerr and J. Newman, 2008. Design of an electrochemical cell making syngas $\left(\mathrm{CO}+\mathrm{H}_{2}\right)$ from $\mathrm{CO}_{2}$ and $\mathrm{H}_{2} \mathrm{O}$ reduction at room temperature. J. Electrochem. Society, 155: B42-B49. DOI: 10.1149/1.2801871

Fan, W., Q. Zhang and Y. Wang, 2013. Semiconductorbased nanocomposites for photocatalytic $\mathrm{H}_{2}$ production and $\mathrm{CO}_{2}$ conversion. Phys. Chem. Chemical Phys., 15: 2632-2649. DOI: $10.1039 / \mathrm{C} 2 \mathrm{CP} 43524 \mathrm{~A}$

Fisher, I.A., A.T. Bell, 1998. In situ infrared study of methanol synthesis from $\mathrm{H}_{2} / \mathrm{CO}$ over $\mathrm{Cu} / \mathrm{SiO}_{2}$ and $\mathrm{Cu} / \mathrm{ZrO}_{2} / \mathrm{SiO}_{2}$. J. Catalysis, 178: 153-173. DOI: $10.1006 /$ jcat.1998.2134

Fujita, S.I., M. Arai and B.M. Bhalch, 2014. Direct Transformation of Carbon Dioxide to Value-Added Product over Heterogeneous Catalysts. In: Transformation and Utilization of Carbon Dioxide, Green Chemistry and Sustainable Technology, Bhanage, B.M. and M. Arai (Eds.), Springer-Verlag Berlin Heidelberg, pp: 39-53.

Gattrell, M., N. Gupta and A. Co, 2006. A review of the aqueous electrochemical reduction of $\mathrm{CO}_{2}$ to hydrocarbons at copper. J. Electroanalytical Chem., 594: 1-19. DOI: 10.1016/j.jelechem.2006.05.013

Gawande, M.B., A. Goswami, F.X. Felpin, T. Asefa and $\mathrm{X}$. Huang et al., 2016. $\mathrm{Cu}$ and Cu-based nanoparticles: Synthesis and applications in catalysis. Chem. Rev., 116: 3722-3811. DOI: $10.1021 /$ acs.chemrev.5b00482

Guemene Dountio, E., P. Meukam, D.L. Pahane Tchaptchet, L.E. Okono Ango and A. Simo, 2016. Electricity generation technology options under the greenhouse gases mitigation scenario: Case study of Cameroon. Energy Strategy Rev., 13-14: 191-211. DOI: 10.1016/j.esr.2016.10.003 
Halmann, M., 1978. Photoelectrochemical reduction of aqueous carbon dioxide on p-type gallium phosphide in liquid junction solar cells. Nature, 275: 115-116. DOI: $10.1038 / 275115 \mathrm{a} 0$

Hara, K., A. Kudo, T. Sakata and M. Watanabe, 1995. High efficiency electrochemical reduction of carbon dioxide under high pressure on a gas diffusion electrode containing Pt catalysts. J. Electrochem. Society, 142: L57-L59. DOI: $10.1149 / 1.2044182$

Heffer PaPh, M., 2013. Fertilizer outlook 2013- 2017. Proceedings of the 81th IFA Annual Conference, (AC' 13).

Herron, J.A., J. Kim, A.A. Upadhye, G.W. Huber and C.T. Maravelias, 2015. A general framework for the assessment of solar fuel technologies. Energy Environ. Sci., 8: 126-157. DOI: 10.1039/C4EE01958J

Hinogami, R., S. Yotsuhashi, M. Deguchi, Y. Zenitani and H. Hashiba et al., 2012. Electrochemical reduction of carbon dioxide using a copper rubeanate metal organic framework. ECS Electrochem. Lett., 1: H17-H19. DOI: $10.1149 / 2.001204$ eel

Hori, Y., 2003. $\mathrm{CO}_{2}$-reduction, catalyzed by metal electrodes. Handbook of fuel cells.

Hori, Y., I. Takahashi, O. Koga and N. Hoshi, 2003. Electrochemical reduction of carbon dioxide at various series of copper single crystal electrodes. J. Molecular Catalysis A, 199: 39-47. DOI: $10.1016 / \mathrm{S} 1381-1169(03) 00016-5$

Hossain, S.K., 2012. Electrochemical reduction of carbon dioxide to hydrocarbons. King Fahd University of Petroleum and Minerals (Saudi Arabia).

Huang, C.H. and C.S. Tan, 2014. A review: $\mathrm{CO}_{2}$ utilization. Aerosol Air Qual. Res., 14: 480-499. DOI: 10.4209 /aaqr.2013.10.0326

Hurst, T.F., T.T. Cockerill and N.H. Florin, 2012. Life cycle greenhouse gas assessment of a coal-fired power station with calcium looping $\mathrm{CO}_{2}$ capture and offshore geological storage. Energy Environ. Sci., 5: 7132-7150. DOI: 10.1039/C2EE21204H

Hurum, D.C., A.G. Agrios, K.A. Gray, T. Rajh and M.C. Thurnauer, 2003. Explaining the enhanced photocatalytic activity of degussa P25 mixed-phase $\mathrm{TiO}_{2}$ using EPR. J. Phys. Chem. B, 107: 4545-4549. DOI: $10.1021 /$ jp0273934

Indrakanti, V.P., J.D. Kubicki and H.H. Schobert, 2009. Photoinduced activation of $\mathrm{CO}_{2}$ on Ti-based heterogeneous catalysts: Current state, chemical physics-based insights and outlook. Energy Environ. Sci., 2: 745-758. DOI: 10.1039/B822176F

Inui, T., M. Anpo, K. Izui, S. Yanagida and T. Yamaguchi, 1998. Advances in Chemical Conversions for Mitigating Carbon Dioxide. 1st Edn., Elsevier, Paises Bajos, ISBN-10: 0080526578, pp: 698 .
Jang, Y.J., J. Lee, J. Lee and J.S. Lee, 2016. Solar hydrogen production from zinc telluride photocathode modified with carbon and molybdenum sulfide. ACS Applied Mater. Interfaces, 8: 7748-7755. DOI: 10.1021/acsami.5b07575

Jhong, H.R.M., S. Ma and P.J.A. Kenis, 2013. Electrochemical conversion of $\mathrm{CO}_{2}$ to useful chemicals: current status, remaining challenges and future opportunities. Curr. Opin. Chem. Eng., 2: 191-199. DOI: 10.1016/j.coche.2013.03.005

Jovanov, Z.P., H.A. Hansen, A.S. Varela, P. Malacrida and A.A. Peterson et al., 2016. Opportunities and challenges in the electrocatalysis of $\mathrm{CO}_{2}$ and $\mathrm{CO}$ reduction using bifunctional surfaces: A theoretical and experimental study of $\mathrm{Au}-\mathrm{Cd}$ alloys. J. Catalysis, 343: 215-231.

DOI: $10.1016 /$ j.jcat.2016.04.008

Kaneco, S., H. Kurimoto, Y. Shimizu, K. Ohta and T. Mizuno, 1999. Photocatalytic reduction of $\mathrm{CO}_{2}$ using $\mathrm{TiO}_{2}$ powders in supercritical fluid $\mathrm{CO}_{2}$. Energy, 24: 21-30. DOI: $10.1016 / \mathrm{S} 0360-5442(98) 00070-\mathrm{X}$

Kaneco, S., Y. Shimizu, K. Ohta and T. Mizuno, 1998. Photocatalytic reduction of high pressure carbon dioxide using $\mathrm{TiO}_{2}$ powders with a positive hole scavenger. J. Photochem. Photobiol. A, 115: 223-226. DOI: 10.1016/S1010-6030(98)00274-3

Kauffman, D.R., D. Alfonso, C. Matranga, H. Qian and R. Jin, 2012. Experimental and computational investigation of $\mathrm{Au}_{25}$ clusters and $\mathrm{CO}_{2}$ : A unique interaction and enhanced electrocatalytic activity. J. Am. Chem. Society, 134: 10237-10243. DOI: $10.1021 /$ ja303259q

Kauffman, D.R., D. Alfonso, C. Matranga, P. Ohodnicki and X. Deng et al., 2014. Probing active site chemistry with differently charged $\mathrm{Au}_{25}{ }^{\mathrm{q}}$ nanoclusters $(\mathrm{q}=-1,0,+1)$. Chem. Sci., 5: 3151-3157. DOI: 10.1039/C4SC00997E

Kauffman, D.R., J. Thakkar, R. Siva, C. Matranga and P.R. Ohodnicki et al., 2015. Efficient electrochemical $\mathrm{CO}_{2}$ conversion powered by renewable energy. ACS Applied Mater. Interfaces, 7: 15626-15632. DOI: 10.1021/acsami.5b04393

Kauffman, D.R., P.R. Ohodnicki, B.W. Kail and C. Matranga, 2011. Selective electrocatalytic activity of ligand stabilized copper oxide nanoparticles. J. Phys. Chem. Lett., 2: 2038-2043.

DOI: $10.1021 / \mathrm{jz} 200850 \mathrm{y}$

Kim, W., T. Seoka and W. Choi, 2012. Nafion layerenhanced photosynthetic conversion of $\mathrm{CO}_{2}$ into hydrocarbons on $\mathrm{TiO}_{2}$ nanoparticles. Energy Environ. Sci., 5: 6066-6070. DOI: 10.1039/C2EE03338K

Kobayashi, T. and H. Takahashi, 2004. Novel $\mathrm{CO}_{2}$ Electrochemical reduction to methanol for $\mathrm{H}_{2}$ storage. Energy Fuels, 18: 285-286. DOI: 10.1021/ef030121v 
Kohno, Y., H. Hayashi, S. Takenaka, T. Tanaka and T. Funabiki et al., 1999. Photo-enhanced reduction of carbon dioxide with hydrogen over $\mathrm{Rh} / \mathrm{TiO}_{2}$. J. Photochem. Photobiol. A, 126: 117-123. DOI: 10.1016/S1010-6030(99)00113-6

Kohno, Y., H. Ishikawa, T. Tanaka, T. Funabiki and S. Yoshida, 2001a. Photoreduction of carbon dioxide by hydrogen over magnesium oxide. Phys. Chem. Chemical Phys., 3: 1108-1113. DOI: $10.1039 / \mathrm{B} 008887 \mathrm{~K}$

Kohno, Y., T. Yamamoto, T. Tanaka and T. Funabiki, 2001b. Photoenhanced reduction of $\mathrm{CO}_{2}$ by $\mathrm{H}_{2}$ over $\mathrm{Rh} / \mathrm{TiO}_{2}$ : Characterization of supported $\mathrm{Rh}$ species by means of infrared and X-ray absorption spectroscopy. J. Molecular Catalysis A, 175: 173-178. DOI: 10.1016/S1381-1169(01)00204-7

Kohno, Y., T. Tanaka, T. Funabiki and S. Yoshida, 2000. Photoreduction of $\mathrm{CO}_{2}$ with $\mathrm{H}_{2}$ over $\mathrm{ZrO}_{2}$. A study on interaction of hydrogen with photoexcited $\mathrm{CO}_{2}$. Phys. Chem. Chemical Phys., 2: 2635-2639. DOI: $10.1039 / \mathrm{B} 001642 \mathrm{~J}$

Kondratenko, E.V., G. Mul, J. Baltrusaitis, G.O. Larrazábal and J. Pérez-Ramírez, 2013. Status and perspectives of $\mathrm{CO}_{2}$ conversion into fuels and chemicals by catalytic, photocatalytic and electrocatalytic processes. Energy Environ. Sci., 6: 3112-3135. DOI: 10.1039/C3EE41272E

Kuhl, K.P., E.R. Cave, D.N. Abram and T.F. Jaramillo, 2012. New insights into the electrochemical reduction of carbon dioxide on metallic copper surfaces. Energy Environ. Sci., 5: 7050-7059. DOI: $10.1039 / \mathrm{C} 2 \mathrm{EE} 21234 \mathrm{~J}$

Kuhl, K.P., T. Hatsukade, E.R. Cave, D.N. Abram and J. Kibsgaard et al., 2014. Electrocatalytic conversion of carbon dioxide to methane and methanol on transition metal surfaces. J. Am. Chem. Society, 136: 14107-14113. DOI: 10.1021/ja505791r

Kumar, B., J.P. Brian, V. Atla, S. Kumari and K.A. Bertram et al., 2016. New trends in the development of heterogeneous catalysts for electrochemical $\mathrm{CO}_{2}$ reduction. Catalysis Today, 270: 19-30. DOI: $10.1016 /$ j.cattod.2016.02.006

Kusama, H., K. Okabe, K. Sayama and H. Arakawa, 1996. $\mathrm{CO}_{2}$ hydrogenation to ethanol over promoted $\mathrm{Rh} / \mathrm{SiO}_{2}$ catalysts. Catalysis Today, 28: 261-266. DOI: 10.1016/0920-5861(95)00246-4

Kushwaha, H.S., N.A. Madhar, B. Ilahi, P. Thomas and A. Halder et al., 2016. Efficient solar energy conversion using $\mathrm{CaCu}_{3} \mathrm{Ti}_{4} \mathrm{O}_{12}$ photoanode for photocatalysis and photoelectrocatalysis. Scientific Rep. DOI: $10.1038 /$ srep18557

Le, M., M. Ren, Z. Zhang, P.T. Sprunger and R.L. Kurtz et al., 2011. Electrochemical reduction of $\mathrm{CO}_{2}$ to $\mathrm{CH}_{3} \mathrm{OH}$ at copper oxide surfaces. J. Electrochem. Society, 158: E45-E49. DOI: 10.1149/1.3561636
Lee, C.H. and M.W. Kanan, 2014. Controlling $\mathrm{H}^{+}$Vs $\mathrm{CO}_{2}$ reduction selectivity on $\mathrm{Pb}$ electrodes. ACS Catalysis, 5: 465-469. DOI: 10.1021/cs5017672

Leung, D.Y.C., G. Caramanna and M.M. Maroto-Valer, 2014. An overview of current status of carbon dioxide capture and storage technologies. Renewable Sustainable Energy Rev., 39: 426-443. DOI: 10.1016/j.rser.2014.07.093

Li, C.W. and M.W. Kanan, 2012. $\mathrm{CO}_{2}$ reduction at low overpotential on $\mathrm{Cu}$ electrodes resulting from the reduction of thick $\mathrm{Cu}_{2} \mathrm{O}$ films. J. Am. Chem. Society, 134: 7231-7234. DOI: 10.1021/ja3010978

Li, K., X. An, K.H. Park, M. Khraisheh and J. Tang, 2014. A critical review of $\mathrm{CO}_{2}$ photoconversion: Catalysts and reactors. Catalysis Today, 224: 3-12. DOI: $10.1016 /$ j.cattod.2013.12.006

Li, P., S. Ouyang, G. Xi, T. Kako and J. Ye, 2012. The effects of crystal structure and electronic structure on photocatalytic $\mathrm{H}_{2}$ evolution and $\mathrm{CO}_{2}$ reduction over two phases of perovskite-structured $\mathrm{NaNbO}_{3}$. J. Phys. Chem. C, 116: 7621-7628. DOI: $10.1021 / \mathrm{jp} 210106 \mathrm{~b}$

Li, Y., W.N. Wang, Z. Zhan, M.H. Woo and C.Y. $\mathrm{Wu}$ et al., 2010. Photocatalytic reduction of $\mathrm{CO}_{2}$ with $\mathrm{H}_{2} \mathrm{O}$ on mesoporous silica supported $\mathrm{Cu} / \mathrm{TiO}_{2}$ catalysts. Applied Catalysis B, 100: 386-392. DOI: $10.1016 /$ j.apcatb.2010.08.015

Liu, L., C. Zhao, H. Zhao, D. Pitts and Y. Li, 2013. Porous microspheres of MgO-patched $\mathrm{TiO}_{2}$ for $\mathrm{CO}_{2}$ photoreduction with $\mathrm{H}_{2} \mathrm{O}$ vapor: Temperaturedependent activity and stability. Chem. Commun., 49: 3664-3666. DOI: 10.1039/C3CC39054C

Liu, L., H. Zhao, J.M. Andino, Y. Li, 2012. Photocatalytic $\mathrm{CO}_{2}$ reduction with $\mathrm{H}_{2} \mathrm{O}$ on $\mathrm{TiO}_{2}$ nanocrystals: Comparison of anatase, rutile and brookite polymorphs and exploration of surface chemistry. ACS Catalysis, 2: 1817-1828. DOI: $10.1021 / \mathrm{cs} 300273 q$

Liu, S., Z. Zhao and Z. Wang, 2007. Photocatalytic reduction of carbon dioxide using sol-gel derived titania-supported $\mathrm{CoPc}$ catalysts. Photochem. Photobiol. Sci., 6: 695-700.

DOI: $10.1039 / \mathrm{B} 613098 \mathrm{D}$

Luu, M.T., D. Milani, A. Bahadori and A. Abbas, 2015. A comparative study of $\mathrm{CO}_{2}$ utilization in methanol synthesis with various syngas production technologies. J. $\mathrm{CO}_{2}$ Utilizat., 12: 62-76. DOI: $10.1016 /$ j.jcou.2015.07.001

Mahmood, M.N., D. Masheder and C.J. Harty, 1987. Use of gas-diffusion electrodes for high-rate electrochemical reduction of carbon dioxide. I. Reduction at lead, indium-and tin-impregnated electrodes. J. Applied Electrochem., 17: 1159-1170. DOI: $10.1007 / \mathrm{BF} 01023599$ 
Manthiram, K., B.J. Beberwyck and A.P. Alivisatos, 2014. Enhanced electrochemical methanation of carbon dioxide with a dispersible nanoscale copper catalyst. J. Am. Chem. Society, 136: 13319-13325. DOI: $10.1021 /$ ja5065284

Olah, G.A., A. Goeppert and G.K.S. Prakash, 2008. Chemical recycling of carbon dioxide to methanol and dimethyl ether: from greenhouse gas to renewable, environmentally carbon neutral fuels and synthetic hydrocarbons. J. Organic Chem., 74: 487-498. DOI: 10.1021/jo801260f

Pan, J., X. Wu, L. Wang, G. Liu and G.Q.M. Lu et al. 2011. Synthesis of anatase $\mathrm{TiO}_{2}$ rods with dominant reactive $\{010\}$ facets for the photoreduction of $\mathrm{CO}_{2}$ to $\mathrm{CH}_{4}$ and use in dye-sensitized solar cells. Chem. Commun., 47: 8361-8363. DOI: $10.1039 / \mathrm{C} 1 \mathrm{CC} 13034 \mathrm{~J}$

Peterson, A.A., J.K. Nørskov, 2012. Activity descriptors for $\mathrm{CO}_{2}$ electroreduction to methane on transitionmetal catalysts. J. Phys. Chem. Lett., 3: 251-258. DOI: $10.1021 / \mathrm{jz} 201461 \mathrm{p}$

Qiao, J., Y. Liu, F. Hong and J. Zhang, 2014. A review of catalysts for the electroreduction of carbon dioxide to produce low-carbon fuels. Chem. Society Rev., 43: 631-675. DOI: $10.1039 / \mathrm{C} 3 \mathrm{CS} 60323 \mathrm{G}$

Qu, Y. and X. Duan, 2012. One-dimensional homogeneous and heterogeneous nanowires for solar energy conversion. J. Mater. Chem., 22: 16171-16181. DOI: 10.1039/C2JM32267F

Razali, N.A.M., K.T. Lee, S. Bhatia, A.R. Mohamed, 2012. Heterogeneous catalysts for production of chemicals using carbon dioxide as raw material: A review. Renewable Sustainable Energy Rev., 16: 4951-4964. DOI: 10.1016/j.rser.2012.04.012

Ren, D., B.S.H. Ang and B.S. Yeo, 2016. Tuning the selectivity of carbon dioxide electroreduction toward ethanol on oxide-derived $\mathrm{Cu}_{\mathrm{x}} \mathrm{Zn}$ catalysts. ACS Catalysis, 6: 8239-8247.

DOI: $10.1021 /$ acscatal.6b02162

Rosen, B.A., A. Salehi-Khojin, M.R. Thorson, W. Zhu and D.T. Whipple et al., 2011. Ionic liquid-mediated selective conversion of $\mathrm{CO}_{2}$ to $\mathrm{CO}$ at low overpotentials. Science, 334: 643-644. DOI: $10.1126 /$ science. 1209786

Roy, S.C., O.K. Varghese, M. Paulose and C.A. Grimes, 2010. Toward solar fuels: Photocatalytic conversion of carbon dioxide to hydrocarbons. ACS Nano, 4: 1259-1278. DOI: $10.1021 / \mathrm{nn} 9015423$

Salehi-Khojin, A., H.R.M. Jhong, B.A. Rosen, W. Zhu and S. Ma et al., 2013. Nanoparticle silver catalysts that show enhanced activity for carbon dioxide electrolysis. J. Phys. Chem. C, 117: 1627-1632. DOI: $10.1021 /$ jp310509z
Sato, S., T. Arai and T. Morikawa, 2016. Carbon microfiber layer as noble metal-catalyst support for selective $\mathrm{CO}_{2}$ photoconversion in phosphate solution: Toward artificial photosynthesis in a single-compartment reactor. J. Photochem. Photobiol. A, 327: 1-5.

DOI: $10.1016 /$ j.jphotochem.2016.04.017

Schouten, K.J.P., Z. Qin, E.P. Gallent and M.T.M. Koper, 2012. Two pathways for the formation of ethylene in $\mathrm{CO}$ reduction on single-crystal copper electrodes. J. Am. Chem. Society, 134: 9864-9867. DOI: $10.1021 /$ ja302668n

Shen, Q., Z. Chen, X. Huang, M. Liu and G. Zhao, 2015. High-yield and selective photoelectrocatalytic reduction of $\mathrm{CO}_{2}$ to formate by metallic copper decorated $\mathrm{Co}_{3} \mathrm{O}_{4}$ nanotube arrays. Environ. Sci. Technol., 49: 5828-5835.

DOI: $10.1021 /$ acs.est.5b00066

Tang, W., A. Peterson, A. Varela, Z. Jovanov and L. Bech et al., 2012. Electrocatalytic process of $\mathrm{CO}$ selectivity in electrochemical reduction of $\mathrm{CO}_{2}$ at metal-electrodes in aqueous-media.

Tornow, C.E., M.R. Thorson, S. Ma, A.A. Gewirth and P.J.A. Kenis, 2012. Nitrogen-based catalysts for the electrochemical reduction of $\mathrm{CO}_{2}$ to CO. J. Am. Chem. Society, 134: 19520-19523.

DOI: $10.1021 / \mathrm{ja} 308217 \mathrm{w}$

Tseng, I.H., J.C.S. Wu and H.Y. Chou, 2004. Effects of sol-gel procedures on the photocatalysis of $\mathrm{Cu} / \mathrm{TiO}_{2}$ in $\mathrm{CO}_{2}$ photoreduction. J. Catalysis, 221: 432-440. DOI: $10.1016 /$ j.jcat.2003.09.002

Tu, W., Y. Zhou, Q. Liu, Z. Tian and J. Gao et al., 2012. Robust hollow spheres consisting of alternating titania nanosheets and graphene nanosheets with high photocatalytic activity for $\mathrm{CO}_{2}$ conversion into renewable fuels. Adv. Funct. Mater., 22: 1215-1221.

DOI: $10.1002 / \mathrm{adfm} .201102566$

USEPA, 2016. United State environmental protection agency: Overview of greenhouse gases.

Varghese, O.K., M. Paulose, T.J. LaTempa and C.A. Grimes, 2009. High-rate solar photocatalytic conversion of $\mathrm{CO}_{2}$ and water vapor to hydrocarbon fuels. Nano Lett., 9: 731-737. DOI: 10.1021/nl803258p

Wang, P.Q., Y. Bai, J.Y. Liu, Z. Fan and Y.Q. Hu, 2012a. One-pot synthesis of rutile $\mathrm{TiO}_{2}$ nanoparticle modified anatase $\mathrm{TiO}_{2}$ nanorods toward enhanced photocatalytic reduction of $\mathrm{CO}_{2}$ into hydrocarbon fuels. Catalysis Commun., 29: 185-188. DOI: $10.1016 /$ j.catcom.2012.10.010

Wang, W.N., W.J. An, B. Ramalingam, S. Mukherjee and D.M. Niedzwiedzki et al., 2012b. Size and structure matter: enhanced $\mathrm{CO}_{2}$ photoreduction efficiency by size-resolved ultrafine Pt nanoparticles on $\mathrm{TiO}_{2}$ single crystals. J. Am. Chem. Society, 134: 11276-11281. DOI: $10.1021 / \mathrm{ja3} 04075 \mathrm{~b}$ 
Wang, W.H., Y. Himeda, J.T. Muckerman, G.F. Manbeck and E. Fujita, 2015. $\mathrm{CO}_{2}$ hydrogenation to formate and methanol as an alternative to photo-and electrochemical $\mathrm{CO}_{2}$ reduction. Chem. Rev., 115: 12936-12973. DOI: $10.1021 /$ acs.chemrev.5b00197

Wang, W.N., J. Park and P. Biswas, 2011. Rapid synthesis of nanostructured $\mathrm{Cu}-\mathrm{TiO}_{2}-\mathrm{SiO}_{2}$ composites for $\mathrm{CO}_{2}$ photoreduction by evaporation driven self-assembly. Catalysis Sci. Technol. 1: 593-600. DOI: 10.1039/C0CY00091D

Wang, W.N., J. Soulis, Y.J. Yang and P. Biswas, 2014. Comparison of $\mathrm{CO}_{2}$ photoreduction systems: A review. Aerosol Air Quality Res., 14: 533-549. DOI: 10.4209/aaqr.2013.09.0283

Windle, C.D. and E. Reisner, 2015. Heterogenised molecular catalysts for the reduction of $\mathrm{CO}_{2}$ to fuels. CHIMIA Int. J. Chem., 69: 435-441. DOI: $10.2533 /$ chimia.2015.435

Wu, J.C.S., 2009. Photocatalytic reduction of greenhouse gas $\mathrm{CO}_{2}$ to fuel. Catalysis Surveys Asia, 13: 30-40. DOI: $10.1007 / \mathrm{s} 10563-009-9065-9$

Xie, S., Q. Zhang, G. Liu and Y. Wang, 2016. Photocatalytic and photoelectrocatalytic reduction of $\mathrm{CO}_{2}$ using heterogeneous catalysts with controlled nanostructures. Chem. Commun., 52: 35-59.

DOI: $10.1039 / \mathrm{C} 5 \mathrm{CC} 07613 \mathrm{G}$
Xu, H., S. Ouyang, P. Li, T. Kato and J. Ye, 2013. Highactive anatase $\mathrm{TiO}_{2}$ nanosheets exposed with $95 \%$ $\{100\}$ facets toward efficient $\mathrm{H}_{2}$ evolution and $\mathrm{CO}_{2}$ photoreduction. ACS Applied Mater. Interfaces, 5: 1348-1354. DOI: 10.1021/am302631b

Yamashita, H., Y. Fujii, Y. Ichihashi, S.G. Zhang and K. Ikeue et al., 1998. Selective formation of $\mathrm{CH}_{3} \mathrm{OH}$ in the photocatalytic reduction of $\mathrm{CO}_{2}$ with $\mathrm{H}_{2} \mathrm{O}$ on titanium oxides highly dispersed within zeolites and mesoporous molecular sieves. Catalysis Today, 45: 221-227. DOI: 10.1016/S0920-5861(98)00219-3

Yuan, Y.J., Z.T. Yu, J.Y. Zhang and Z.G. Zou, 2012. A copper (I) dye-sensitised $\mathrm{TiO}_{2}$-based system for efficient light harvesting and photoconversion of $\mathrm{CO}_{2}$ into hydrocarbon fuel. Dalton Trans., 41: 9594-9597. DOI: $10.1039 / \mathrm{C} 2 \mathrm{DT} 30865 \mathrm{G}$

Zhang, S., P. Kang and T.J. Meyer, 2014. Nanostructured tin catalysts for selective electrochemical reduction of carbon dioxide to formate. J. Am. Chem. Society, 136: 1734-1737. DOI: $10.1021 /$ ja4113885

Zhao, H., L. Liu, J.M. Andino and Y. Li, 2013. Bicrystalline $\mathrm{TiO}_{2}$ with controllable anatase-brookite phase content for enhanced $\mathrm{CO}_{2}$ photoreduction to fuels. J. Mater. Chem. A, 1: 8209-8216. DOI: $10.1039 / \mathrm{C} 3 \mathrm{TA} 11226 \mathrm{H}$ 